\title{
ADAKAH RELEVAN PENAWARAN TAKAFUL MIKRO KEPADA WARGA EMAS BERSAMA JABATAN KEBAJIKAN MASYARAKAT (JKM)?*
}

\section{Is It Relevant to Offer Microtakaful to the Elderly in Cooperation with the Department of Social Welfare (JKM)?}

\author{
Asiah Kamal ${ }^{1}$ \\ Ahmad Azam Sulaiman@Mohamad ${ }^{2}$ \\ Mohammad Taqiuddin Mohamad ${ }^{3}$
}

\begin{abstract}
Malaysia is expected to reach an aged population by 2030. Currently, micro takaful under the "Perlindungan Tenang"
\end{abstract}

\footnotetext{
Artikel ini merupakan output penyelidikan di bawah Geran Penyelidikan Universiti Malaya (UMRG Programme)-HNE (Humanities \& Ethics) bertajuk "Microtakaful As An Islamic Financial Instrument: A Study of the Elderly Muslim In Malaysia" (RP028A-16HNE). Penghargaan ditujukan kepada biasiswa Sasakawa Young Leaders Fellowship Fund (SYLFF) di bawah unit biasiswa dan tajaan, Universiti Malaya; Jabatan Kebajikan Masyarakat (JKM); Bank Negara Malaysia (BNM) dan tiga Pengendali Takaful yang terlibat iaitu AIA Public Takaful, Prudential BSN Takaful dan Takaful Ikhlas atas kerjasama yang diberikan.

1 PhD Candidate, Department of Shariah and Economics, Academy of Islamic Studies, University of Malaya, 50603 Kuala Lumpur, Malaysia, asiahkamal510@ gmail.com.

2 Senior Lecturer, Department of Shariah and Economics, Academy of Islamic Studies, University of Malaya, 50603 Kuala Lumpur, Malaysia, ahmadazams@, um.edu.my.

3 Senior Lecturer, Department of Shariah and Economics, Academy of Islamic Studies, University of Malaya, 50603 Kuala Lumpur, Malaysia, m.taqiuddin@ um.edu.my
} 
initiative, does not promote the participation of the elderly in line with the increasing life expectancy of the country. This is mainly due to the link between the high risk of age-related-illness. For the microtakaful offering segment, takaful operators should not expect immediate profit. Therefore, the study was conducted to look at collaboration opportunities between takaful operators and the Department of Social Welfare (JKM) by offering microtakaful to senior citizens in the country. Befittingly this collaboration has allowed for the government department, JKM, to provide direct service to senior citizens. Thus, field studies were conducted with JKM, takaful operators and the Central Bank of Malaysia (BNM). Interviews with JKM involved a group of senior citizens, and also members of the productive welfare and a sample of the community. Interviews with takaful operators included AIA Public Takaful in the Product Marketing Department, Prudential BSN Takaful under microtakaful and CSR Department and IKHLAS Takaful in the Bancatakaful Department. Interviews with BNM were conducted with the Islamic Banking and Takaful Department. The offering of microtakaful to senior citizens living in institutions under the JKM and senior citizens receiving financial assistance ie "Bantuan Orang Tua (BOT)" is made possible through funds from zakat, waqf and CSR in the form of non-commercial microtakaful. Whereas senior citizens living in the community can be offered commercial microtakaful through community cooperation, Elderly Care Centres, both from NGOs and privately registered centres have been cooperating with JKM to describe the value and importance of increasing understanding as well awareness of microtakaful. At the same time, microtakaful schemes need to make product design improvements to be relevant and appropriate for senior citizens, especially in terms of target schemes and supply channels.

Keywords: senior citizens, Department of Social Welfare (JKM), microtakaful, perlindungan tenang, Central Bank of Malaysia (BNM)

\section{PENGENALAN}

Pada tahun 2017, BNM dengan kerjasama pengendali takaful telah memperkenalkan Perlindungan Tenang sebagai inisiatif untuk memberi 
galakan kepada pengendali takaful menawarkan takaful mikro di pasaran. ${ }^{4}$ Kelebihan skim ini ditawarkan dengan caruman yang berpatutan, sijil penyertaan yang ringkas dan mudah untuk difahami, proses penyertaan serta tuntutan yang mudah. ${ }^{5} \mathrm{Kini}$, terdapat tiga pengendali takaful yang telah menawarkan takaful mikro menepati Perlindungan Tenang iaitu AIA Public takaful, Prudential BSN Takaful dan Takaful Ikhlas. ${ }^{6}$ Penawaran takaful mikro ditawarkan dengan manfaat perlindungan yang kecil. Namun, perlindungan ini merupakan nilai yang besar bagi golongan miskin. Oleh itu, skim ini sesuai untuk disertai oleh kumpulan yang berpendapatan rendah dan kurang berkemampuan untuk menyertai takaful komersial. Begitu juga dengan warga emas, terdapat kumpulan warga emas yang berpendapatan rendah dan kurang berkemampuan terutamanya warga emas di bawah sasaran JKM.

Kajian ini dilakukan terhadap warga emas di bawah sasaran JKM kerana JKM merupakan jabatan di bawah Kementerian Pembangunan Wanita, Keluarga dan Masyarakat (KPWKM) yang mewakili pihak kerajaan dalam menjaga kebajikan warga emas di negara ini. Kajian ini juga dijalankan seiring dengan peningkatan jangka hayat penduduk di negara ini yang dijangkakan mencapai status negara tua pada tahun 2030 oleh KPWKM. ${ }^{7}$ Manakala, Institut Penyelidikan Penuaan Malaysia, Universiti Putra Malaysia (UPM) pula menjangkakan status negara tua di negara ini adalah pada tahun $2035^{8}$ iaitu apabila penduduk yang berumur 60 tahun dan ke atas mencapai 15\%

$4 \quad$ Responden 4 (Penganalisis, Jabatan Perbankan Islam dan Takaful, Bank Negara Malaysia), dalam temu bual beliau bersama penulis pada 15 Februari 2019.

5 Malaysia Takaful Association, 'Perlindungan Tenang' laman sesawang Malaysia Takaful Association, http:/www.malaysiantakaful.com.my/Consumer-Zone/ Perlindungan-Tenang.aspx., dicapai pada 5 April 2019.

6 Responden 4 (Penganalisis, Jabatan Perbankan Islam dan Takaful, Bank Negara Malaysia), dalam temu bual beliau bersama penulis pada 15 Februari 2019.

7 Kementerian Pembangunan Wanita, Keluarga dan Masyarakat, Dasar dan Pelan Tindakan Warga Emas Negara (Putrajaya: Jabatan Kebajikan Masyarakat, t.t.), 3.

8 Institut Penyelidikan Penuaan Malaysia Universiti Putra Malaysia, Kebajikan Kemudahan dan Perkhidmatan bagi menepati keperluan warga emas menjelang 2030 (Putrajaya: Jabatan Kebajikan Masyarakat, 2017), 1. 
daripada jumlah keseluruhan penduduk bersamaan dengan bilangan warga emas seramai 5.6 juta orang. ${ }^{9}$

Penawaran takaful mikro kepada warga emas semakin relevan untuk dibincang kerana skim takaful mikro yang terdapat di pasaran tidak turut sama mensasarkan warga emas walaupun jangka hayat penduduk di negara ini telah meningkat. Hal ini kerana warga emas mempunyai risiko tinggi dari segi umur dan tahap kesihatan. ${ }^{10}$ Semakin meningkat usia, semakin tinggi caruman yang perlu dibayar, sejajar dengan risiko tuntutan yang meningkat, 11 pengendali takaful mengambil kira risiko tersebut menyebabkan polisi yang terdapat di pasaran tidak mensasarkan warga emas. Hal ini, dapat dilihat terdapat diskrimisi dalam penawaran skim takaful kepada warga emas. ${ }^{12} \mathrm{Oleh}$ itu, penawaran takaful mikro kepada warga emas wajar dibincang. Tambahan, rawatan di hospital Kementerian Kesihatan Malaysia (KKM) diberi subsidi yang tinggi daripada kerajaan. Namun, sebahagian kos alat perubatan masih perlu ditanggung oleh pesakit seperti kos untuk perentak jantung, implan untuk tulang belakang dan sebagainya, kos ini menambah beban kewangan kepada kumpulan yang kurang berkemampuan. ${ }^{13}$ Manakala, bantuan JKM kepada warga emas pula, terhad kepada warga emas yang tinggal di institusi serta perkhidmatan yang berbentuk komuniti supaya tidak berlaku peningkatan warga emas ke institusi. ${ }^{14}$

Justeru, bagi segmen takaful mikro, pengendali takaful sepatutnya tidak mengharapkan keuntungan segera seperti yang dinyatakan oleh Craig Churchill

9 Institut Penyelidikan Penuaan Malaysia Universiti Putra Malaysia, Kebajikan Kemudahan dan Perkhidmatan bagi menepati keperluan warga emas menjelang 2030, 1; Kementerian Pembangunan Wanita, Keluarga dan Masyarakat, Dasar dan Pelan Tindakan Warga Emas Negara, 3; Farhana Hanim Mohd Mydin, 'Warga emas di Malaysia meningkat 2.8 juta orang,' KOSMO, http://ww1.kosmo. com.my $/$ kosmo/content.asp? $\mathrm{y}=2016 \& \mathrm{dt}=0324 \& \mathrm{pub}=\mathrm{Kosmo} \& \mathrm{sec}=\mathrm{Negara} \& \mathrm{pg}=$ ne_02.htm, dicapai pada 7 Mei 2018.

10 Agensi Kaunseling dan Pengurusan Kredit, Celik Wang Pengurusan Wang secara Bijak (Kuala Lumpur: Agensi Kaunseling dan Pengurusan Kredit, 2014), 73.

11 Agensi Kaunseling dan Pengurusan Kredit, Celik Wang Pengurusan Wang secara Bijak, 73.

12 Institut Penyelidikan Penuaan Malaysia Universiti Putra Malaysia, Kebajikan Kemudahan dan Perkhidmatan bagi menepati keperluan warga emas menjelang 2030, 520-522.

13 PeKa B40, 'Utama', laman sesawang Peka B40, https://www.pekab40.com.my/, dicapai pada 22 November 2019

14 Responden 1 (Ketua Penolong Pengarah Kanan, Bahagian Warga Emas (Cawangan Perkhidmatan Institusi), Jabatan Kebajikan Masyarakat), dalam temu bual beliau bersama penulis pada 22 November 2018 . 
bahawa penawaran yang terbaik kepada pelanggan di segmen takaful mikro memerlukan pengendali takaful menjangkakan akan memperolehi pulangan sebenar hanya dalam tempoh jangka masa panjang yang akan mengambil masa bertahun-tahun. Usaha untuk menjana pulangan pantas boleh memberi kesan negatif kepada industri takaful. Sebaliknya, fokus utama adalah dengan memaksimumkan kesetiaan pelanggan dengan menjangkakan bahawa isi rumah berpendapatan rendah hari ini mungkin akan berada di kelas pertengahan pada masa akan datang yang memerlukan lebih besar jumlah yang perlu dijamin dan pertambahan perlindungan. ${ }^{15}$

Demikian, tujuan kajian ini dilakukan seiring dengan peningkatan warga emas yang semakin meningkat dan rancak diperbincangkan pada masa kini kerana pelbagai pihak perlu bersedia menghadapi negara tua yang turut memerlukan perlindungan takaful mikro pada masa akan datang. Secara asasnya konteks perbincangan dalam kajian ini adalah berkaitan penawaran takaful mikro di bawah Perlindungan Tenang dengan analisis penyertaan warga emas secara umum serta penyertaan warga emas yang tinggal di institusi dan dalam komuniti di bawah sasaran JKM.

\section{PERSOALAN KAJIAN}

a) Adakah relevan penawaran takaful mikro kepada warga emas di bawah JKM?

b) Siapakah yang akan membayar caruman bagi penyertaan warga emas dalam takaful mikro di bawah JKM?

c) Bagaimanakah saluran penawaran takaful mikro kepada warga emas di bawah JKM dapat ditawarkan?

\section{DEFINISI TAKAFUL MIKRO DAN WARGA EMAS}

Definisi takaful mikro dirujuk daripada kajian insurans mikro. Hal ini, kerana takaful mikro belum dibincangkan secara meluas. Tambahan, konsep penawaran insurans mikro dan takaful mikro adalah sama. Namun, terdapat perbezaan takaful dan insurans seperti yang diketahui umum iaitu takaful merupakan skim takaful yang menawarkan perlindungan yang menepati konsep syariah dalam operasinya. Manakala insurans pula merupakan perlindungan yang

15 Craig Churchill, 'Insuring the Low-Income Market: Challenges and Solutions for Commercial Insurers,' The Genera Papers on Risk and Insurance, no. 32 (2007): 408 . 
menggunakan operasi secara konvensional. ${ }^{16}$ Oleh itu, terdapat sebahagian besar rujukan dalam perbincangan asal yang merujuk kepada insurans mikro tetapi menggunakan istilah takaful mikro dalam perbincangan artikel ini tanpa menyentuh berkaitan operasinya.

Menurut Tajudeen Olalekan Yusuf, takaful mikro ditakrifkan sebagai takaful untuk golongan miskin. ${ }^{17}$ Skim ini merujuk kepada pasaran tertentu yang dikhaskan kepada kumpulan masyarakat yang mempunyai pendapatan rendah ${ }^{18}$ dan golongan miskin. ${ }^{19}$ Tujuan utama takaful mikro adalah bagi membantu golongan yang berpendapatan rendah supaya turut mempunyai hak untuk mendapatkan perlindungan (protection) dan keselamatan (security) apabila ditimpa sebarang musibah. ${ }^{20}$

Nikunjkumar $\mathrm{Go}^{21}$ menyatakan takaful mikro juga bertujuan membantu dan bukan untuk mendapatkan keuntungan semata-mata. Definisi takaful mikro bagi Daniel J. Clarke dan Dermot Grenham ${ }^{22}$ merupakan takaful premium kecil yang mempunyai potensi besar untuk meningkatkan jumlah pemegang polisi atau peserta. Istilah takaful mikro dianggap sinonim dengan bantuan

16 Jamil Ramly et al., Buku Panduan Asas Takaful (Kuala Lumpur: IBFIM, 2010), 58-59.

17 Tajudeen Olalekan Yusuf, 'The Role of Islamic Micro Insurance in Economic Growth and Development: The Nigerian Experience: A Case Study of Al-Barakah Microfinance Bang, Lagos,' International Journal of Business and Commerce, vol. 1/10 (2012): 108; Seiro Ito \& Hisaki Kono, 'Why is The Take-up of Microinsurance so Low? Envidence from A Health Insurance Scheme in India,' The Developing Economies, vol. 48/1 (2010): 74.

18 Craig Churchill, 'Insuring the Low-Income Market: Challenges and Solutions for Commercial Insurers,' 403.

19 Fatin Nabilah Abdul Wahid \& Kamaruzaman Noordin, 'Skim Takaful Sumbangan Rendah serta Prospek Pelaksanaan Takaful Mikro di Malaysia,' (Paper presented, International Conference on Postgraduate Research (ICPR), Kuala Lumpur, 2014), 31; Vishal Pinto, 'Role of NGOs in Promoting Micro Health Insurance: A Study with Reference to 'Sampoorna Saraksha' Health Insurance Scheme by SKDRDP, Mangalore (India),' South Asia Journal of Business and Management Cases, vol. 4/2 (2015): 252.

20 Sheila Nu Nu Htay, Nur Shazwani Sadzali \& Hanudin Amin, 'An Analysis of the Viability of Micro Health Takaful in Malaysia,' Journal of Islamic Accounting and Business Research, vol. 4/1 (2015): 63.

21 Nikunjkumar Gor, 'Microtakaful-Islamic Insurance For Deprived: Innovation, Sustainability and Inclusive Growth,' International Journal of Business, Economics and Law, vol. 3/2 (2013): 24.

22 Daniel J. Clarke \& Dermot Grenham, 'Microinsurance and Natural Disasters: Challenges and Options,' Environmental Science and Policy, vol. 27 (2013): S90. 
bersama; terdapat sesetengah penulisan percaya bahawa perlu digunakan secara eksklusif untuk menandakan perkhidmatan organisasi bukan kerajaan secara formal terbentuk. ${ }^{23}$ Takaful mikro juga merupakan alat pengurusan risiko yang menanggung kerugian pemegang polisi terhadap risiko tertentu dalam tempoh tertentu. Sebagai contoh mikro kredit berfungsi untuk melindungi isi rumah daripada kecairan aset untuk membayar pinjaman; takaful kesihatan pula menghalang kemungkinan daripada menggunakan pinjaman yang diluluskan untuk pembayaran bil hospital dan takaful harta seperti polisi kebakaran dapat menghalang isi rumah daripada risiko tidak dapat membayar semula pinjaman. ${ }^{24}$

Oleh itu, takaful mikro berfungsi sebagai mekanisma kemanusiaan, perniagaan atau kedua-dua sekali. ${ }^{25}$ Demikian, takaful mikro boleh diringkaskan sebagai penawaran takaful yang berkos rendah yang ditawarkan kepada golongan miskin dan pendapatan rendah dengan tujuan memberi perlindungan risiko yang sesuai kepada golongan ini.

Bagi definisi warga emas pula, merupakan golongan yang berusia 60 tahun keatas. Definisi ini dijelaskan berdasarkan World Assembly On Ageing 1982 di Vienna yang digunapakai oleh JKM. ${ }^{26}$ Secara ringkasnya, kajian ini menumpukan takaful berkos rendah kepada masyarakat yang berumur 60 tahun ke atas.

\section{SASARAN PENAWARAN TAKAFUL MIKRO}

Takaful mikro dapat dikaitkan dengan sasaran penawaran yang melibatkan kumpulan berikut:

23 James Midgley, 'Social Protection and the Elderly in the Developing World: Mutual Aid, Micro-Insurance and the State,' Journal of Comparative Social Welfare, vol. 28/2 (2012): 157.

24 Joseph Oscar Aktey \& Charles K.D. Adjasi, 'Dose Microcredit Increase Household Welfare in the Absence of Microinsurance?' World Development, vol. 77 (2016): 389.

25 Rebekah Yore \& Joanna Faure Walker, 'Microinsurance for Disaster Recovery: Business Venture or Humanitarian Intervention?: An Analysis of Potential Success and Failure Factors of Microinsurance Case Studies,' International Journal Disaster Risk Reduction, vol. 33 (2019): 26.

26 Kementerian Pembangunan Wanita, Keluarga dan Masyarakat, 'Definisi Warga Emas,' laman sesawang Jabatan Kebajikan Masyarakat, http://www.jkm.gov. my/jkm/index.php?r=portal/left\&id=VEpUUXV3THFURkZETmxWNjZpQ1BX dz09., dicapai pada 5 April 2019. 


\section{Sasaran kepada Orang Miskin dan Berpendapatan Rendah}

Takaful mikro menyediakan perkhidmatan takaful kepada golongan miskin di negara-negara miskin dan sedang membangun seperti yang dibincangkan oleh Ralf Radermacher dan Johannes Brinkmann, ${ }^{27}$ Shuaibu Mukhtar, ${ }^{28}$ dan Vishal Pinto. ${ }^{29}$ Takaful mikro mensasarkan bahaya (peril) secara khusus yang mempengaruhi isi rumah berpendapatan rendah. ${ }^{30}$ Hal ini, kerana golongan berpendapatan rendah terkecuali daripada polisi takaful di pasaran disebabkan harga yang mahal dan tidak mampu dibeli oleh golongan ini. ${ }^{31}$ Begitu juga dengan takaful kesihatan mikro menyediakan perkhidmatan kepada negaranegara yang berpendapatan rendah dan sederhana untuk mencapai liputan kesihatan secara meluas. ${ }^{32}$

Kumpulan insurans Allianz Jerman adalah antara firma insurans swasta yang pertama meneroka potensi pasaran insurans mikro kepada masyarakat berpendapatan rendah dan didapati penawaran produk-produk insurans mikro mula ditawarkan pada tahun 2007. ${ }^{33}$ Bagi produk takaful yang berkos rendah sesuai dengan keperluan pelanggan yang berpendapatan rendah dengan memberi perkhidmatan yang adil kepada semua lapisan masyarakat untuk menguruskan risiko yang sepatutnya ditawarkan oleh pengendali takaful. ${ }^{34}$

27 Ralf Radermacher \& Johannes Brinkmann, 'Insurans for the Poor? First Thought about Microinsurance Business Ethic,' Journal of Business Ethic, vol. 103 (2011): 63.

28 Shuaibu Mukhtar, 'Insuring the Uninsurable for Poverty Alleviation in Nigeria: What Micro-Insurance can do?,' Mediterranean Journal of Social Science, vol. 4/2 (2013): 379.

29 Ralf Radermacher \& Johannes Brinkmann, 'Insurans for the Poor? First Thought about Microinsurance Business Ethic,' 63.

30 Daniel J. Clarke \& Dermot Grenham, 'Microinsurance and Natural Disasters: Challenges and Options,' S90.

31 Vishal Pinto, 'Role of NGOs in Promoting Micro Health Insurance: A Study with Reference to 'Sampoorna Saraksha' Health Insurance Scheme by SKDRDP, Mangalore (India),' 251.

32 Lauren Peterson et al., 'Extending Health Insurance Coverage to the Informal Sector: Lessons from a Private Micro Health Insurance Scheme in Logos, Nigeria,' International Journal of Health Plan and Management (2018): 1.

33 Sirojudin \& James Midgley, 'Microinsurance and Social Protection: The Social Welfare Insurance Program for Informal Sector Workers in Indonesia', Journal of Policy Practice, 11/1-2 (2012): 128.

34 B. Zaheenah Chummun \& Christo A Bisschoff, 'A Perspective of Microinsurance (MI): The Case of South Africa,' Mediterranean Journal of Social Science, vol. 5/23 (2014): 70 . 
Selain itu, takaful mikro merupakan skim perlindungan yang dapat memberi perlindungan kepada isi rumah berpendapatan rendah yang terdiri daripada peniaga dan petani kepada akses kecairan selepas berlaku bencana. Sekaligus, dapat melindungi kehidupan golongan ini membina kehidupan semula. ${ }^{35}$ Pasaran insurans mikro di Afrika telah berlaku perubahan secara drastik dalam tempoh beberapa tahun setelah Persatuan Life Office Association South Africa (LOASA) dan syarikat-syarikat insurans telah mencapai kata sepakat dengan Sektor Piagam Kewangan Afrika Selatan atau Financial Sector Charter of South Africa untuk melancarkan produk dan perkhidmatan khusus untuk rakyat berpendapatan rendah iaitu insurans mikro. ${ }^{36}$

\section{Sasaran kepada Sektor Tidak Formal}

Markus Loewe ${ }^{37}$ menyatakan skim takaful mikro memberi tumpuan kepada pekerja dalam sektor tidak formal yang sebahagian besarnya tidak dilindungi. Oscar Joseph Akotey, Kofi A. Osei dan Albert Gemegah ${ }^{38}$ juga menyatakan takaful mikro merupakan instrumen pengurusan risiko kewangan yang berkesan serta dapat membantu sektor tidak formal untuk mengurangkan risiko kesusahan dan kemiskinan. Sektor tidak formal melibatkan pekerjaan sebagai petani, ${ }^{39}$ peniaga kecil ${ }^{40}$ atau usahawan mikro. ${ }^{41}$

35 Shuaibu Mukhtar, 'Insuring the Uninsurable for Poverty Alleviation in Nigeria: What Micro-Insurance can do?,' 375.

36 B. Zaheenah Chummun \& Christo A Bisschoff, 'A Perspective of Microinsurance (MI): The Case of South Africa,' 63.

37 Markus Loewe, 'New Avenues to be Opened for Social Protection in the Arab World: The Case of Egypt,' International Journal of Social Welfare, no. 13 (2004): 3.

38 Oscar Joseph Akotey, Kofi A. Osei \& Albert Gemegah, 'The Demand for Micro Insurance in Ghana,' The Journal of Risk Finance, vol. 12/3 (2011): 191.

39 Shuaibu Mukhtar, 'Insuring the Uninsurable for Poverty Alleviation in Nigeria: What Micro-Insurance can do?,' 375; Daniel J. Clarke \& Dermot Grenham, 'Microinsurance and Natural Disasters: Challenges and Options,' S93-S94; Yaya Koloma, 'Crop Microinsurance for Maize Farmers in Burkina Faso: Access and Agriculture Performance in Dandé Village,' Strategi Change: Briefing in Entrepreneurial Finance, vol. 24/1 (2015): 118; Michal Matual et al., 'Microinsurance Demand: Determinants and Strategies,' Enterprise Development and Microfinance, vol. 24/4 (2013): 315.

40 Shuaibu Mukhtar, 'Insuring the Uninsurable for Poverty Alleviation in Nigeria: What Micro-Insurance can do?,' 375.

41 Craig Churchill, 'Trying To Understand The Demand for Microinsurance,' Journal of International Development, vol. 14 (2002): 381-387. 
Takaful kesihatan mikro menyediakan perkhidmatan kepada negara-negara yang berpendapatan rendah dan sederhana untuk mencapai liputan kesihatan secara meluas kepada pekerja di sektor tidak formal. ${ }^{42}$ Responden lebih daripada 90\% yang dikenal pasti bekerja di sektor tidak formal yang dikecualikan daripada mendapat perlindungan takaful kesihatan dan merupakan ketua isi rumah yang mempunyai peranan dalam membuat keputusan berkaitan penjagaan kesihatan. ${ }^{43}$ Skim takaful mikro menjadi bukti kejayaan dalam mengatasi halangan paling mencabar kepada Universal Health Care (UHC) untuk membantu sektor tidak formal di negara berpendapatan rendah serta penduduk miskin di pendalaman. ${ }^{44}$

Secara ringkasnya, penyertaan takaful mikro adalah daripada kumpulan yang mempunyai kekurangan dari aspek dana, pendidikan dan pekerjaan. ${ }^{45}$ Tambahan, takaful kesihatan mikro pula ditawarkan dengan harga polisi yang rendah dan harga premium yang mengikut tahap pendapatan kumpulan ini. ${ }^{46}$ Oleh itu, takaful kesihatan mikro dapat disasarkan secara menyeluruh tanpa mengabaikan kumpulan tertentu masyarakat dalam sesebuah negara. ${ }^{47}$ Afrika Selatan menghadapi Insurance Gap kira-kira 61\% daripada isi rumah berpendapatan rendah tidak mempunyai takaful yang menjadi peluang besar kepada industri untuk menawarkan takaful mikro. Oleh itu, pengenalan produk Zimele yang diklasifikasikan sebagai produk insurans mikro pada tahun 2007 adalah pelancaran yang sangat baik untuk di sasarkan kepada kumpulan yang tidak mendapat perlindungan takaful. ${ }^{48}$ Takaful mikro juga mensasarkan kepada

42 Lauren Peterson et al., 'Extending Health Insurance Coverage to the Informal Sector: Lessons from a Private Micro Health Insurance Scheme in Logos, Nigeria,' 1 .

43 Lauren Peterson et al., 'Extending Health Insurance Coverage to the Informal Sector: Lessons from a Private Micro Health Insurance Scheme in Logos, Nigeria,' 10 .

44 David M. Dror et al., 'Implementing A Participatory Model of Micro Health Insurance among Rural Poor with Evidence from Nepal,' The Geneva Paper, vol. 39 (2014): 298.

45 Mohammed Ahmad Uddin, 'Microinsurance in India: Insurance Literacy and Demand,' Business and Economic Horizons, vol. 3/2 (2017): 189.

46 Vishal Pinto, 'Role of NGOs in Promoting Micro Health Insurance: A Study with Reference to 'Sampoorna Saraksha' Health Insurance Scheme by SKDRDP, Mangalore (India),' 261.

47 Sheila Nu Nu Htay, Nur Shazwani Sadzali \& Hanudin Amin, 'An Analysis of the Viability of Micro Health Takaful in Malaysia,' 63.

48 B. Zaheenah Chummun \& Christo A Bisschoff, 'A Perspective of Microinsurance (MI): The Case of South Africa,' 63. 
kumpulan yang tidak mampu menyertai takaful dan takaful sosial. ${ }^{49}$ Oleh itu, takaful mikro sering dikaitkan dengan golongan miskin, berpendapatan rendah dan bekerja di sektor tidak formal yang pada kebiasaannya bekerja sebagai petani, peniaga kecil dan usahawan mikro.

Rajah 1: Ringkasan Perbezaan Takaful, Takaful Sosial dan Takaful Mikro Berdasarkan Sasaran

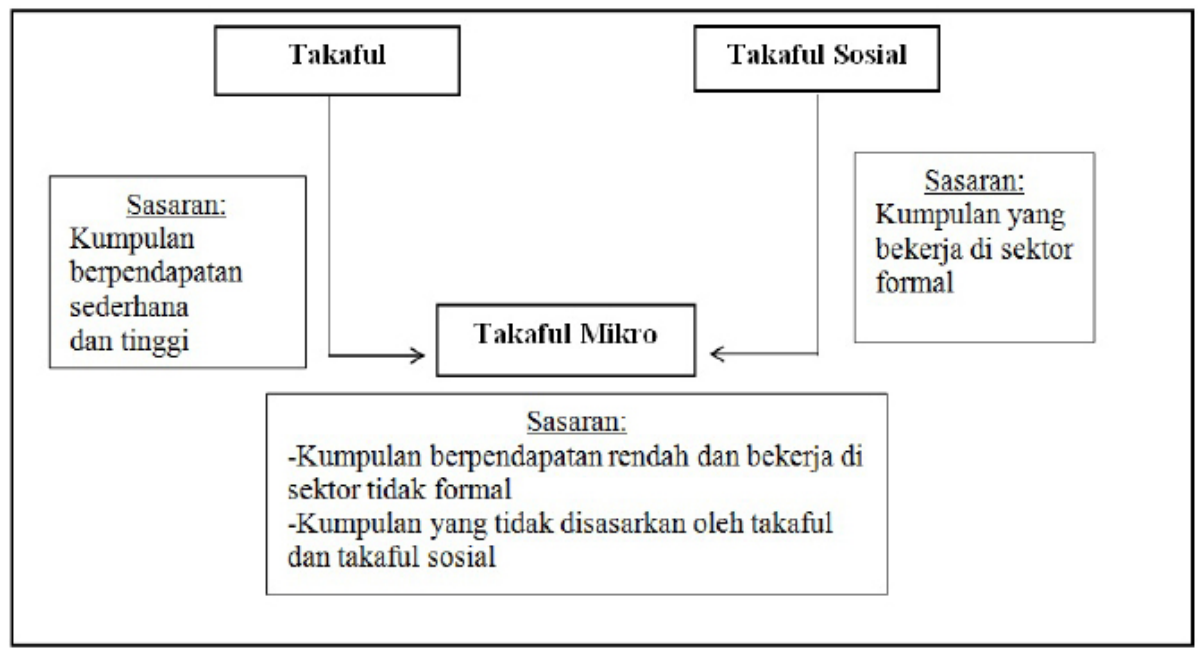

Sumber: Gambaran penyelidik

\section{PENAWARAN PRODUK DI BAWAH TAKAFUL MIKRO}

Penawaran produk adalah berdasarkan risiko yang dihadapi oleh kumpulan sasaran yang ingin mendapatkan perlindungan. Berdasarkan kajian-kajian lepas, skim takaful mikro menawarkan enam produk di bawah skim ini. Pertama, takaful hayat ${ }^{50}$ mendapat peratusan tertinggi terutamanya polisi takaful hayat kredit yang selalunya dibeli bersama produk mikro kredit. ${ }^{51}$ Kedua, takaful kesihatan telah berjaya di tawarkan di India sejak tahun 2004 di bawah program The Shri Kshetra Dharmasthala Rural Development

49 W. Kron, 'Flood Insurance: From Clients to Global Financial Markets,' Journal of Flood Risk Management, vol. 2 (2009): 74.

50 Vishal Pinto, 'Role of NGOs in Promoting Micro Health Insurance: A Study with Reference to 'Sampoorna Saraksha' Health Insurance Scheme by SKDRDP, Mangalore (India),' 253.

51 Christian Biener \& Martin Eling, 'Insurability in Microinsurance Markets: An Analysis of Problem and Potential Solutions,' The Geneva on Risk and Insurance, vol. 37 (2012): 79. 
Programme (SKDRDP) yang merupakan takaful mikro yang memberi tumpuan kepada kos perubatan dan hospitaliti kepada golongan miskin di bawah skim Sampoorna Suraksha dan telah mendapat sambutan baik. ${ }^{52} \mathrm{Di}$ Pakistan, keperluan kepada perlindungan kesihatan yang berpatutan dan berkualiti untuk golongan miskin ditawarkan di bawah skim takaful kesihatan mikro yang telah ditubuhkan dengan bantuan kewangan daripada penderma dengan harapan skim ini akan terus kekal sehingga jangka masa panjang. ${ }^{53} \mathrm{Di}$ Malaysia, produk takaful kesihatan mikro masih dalam kajian penerokaan dan belum ditawarkan, kajian tersebut menerangkan pandangan berkaitan maklum balas daripada BNM, pengendali takaful, pihak berkuasa zakat, pandangan sarjana syariah dan pandangan peserta terhadap penyertaan produk yang ingin dilaksanakan. ${ }^{54}$

Ketiga, takaful kecacatan atau hilang keupayaan kekal ${ }^{55}$ merupakan produk yang biasa ditawarkan di bawah takaful mikro. Keempat, takaful harta yang melibatkan perbincangan di bawah takaful harta adalah skim takaful banjir di Jakarta, Indonesia yang masih diperingkat cadangan penawaran dalam artikel oleh W.Kron. ${ }^{56}$ Walau bagaimanapun, skim takaful banjir sesuai ditawarkan di bawah skim takaful mikro bagi negara miskin dan sedang membangun kerana skim ini tidak ditawarkan di bawah skim takaful komersial dan takaful sosial. Selain itu, di bawah perbincangan takaful harta termasuk takaful tanaman dan takaful cuaca seperti hujan, banjir, kemarau dan bencana alam bagi petani yang dibincangan oleh Vishal Pinto, ${ }^{57}$ Yaya Koloma,${ }^{58}$ Sonia Akter et al. ${ }^{59}$ Jacqueline

52 Vishal Pinto, 'Role of NGOs in Promoting Micro Health Insurance: A Study with Reference to 'Sampoorna Saraksha' Health Insurance Scheme by SKDRDP, Mangalore (India),' 260.

53 Yi (Kitty) Yao, 'Development and Sustainability of Emerging Health Insurance Markets: Evidence from Microinsurance in Pakistan,' The Geneva Pepers, vol. 38 (2013): 178.

54 Sheila Nu Nu Htay, Nur Shazwani Sadzali \& Hanudin Amin, 'An Analysis of the Viability of Micro Health Takaful in Malaysia,' 63.

55 Vishal Pinto, 'Role of NGOs in Promoting Micro Health Insurance: A Study with Reference to 'Sampoorna Saraksha' Health Insurance Scheme by SKDRDP, Mangalore (India),' 253.

56 W. Kron, 'Flood Insurance: From Clients to Global Financial Markets,' 68-75.

57 Vishal Pinto, 'Role of NGOs in Promoting Micro Health Insurance: A Study with Reference to 'Sampoorna Saraksha' Health Insurance Scheme by SKDRDP, Mangalore (India),' 253.

58 Yaya Koloma, 'Crop Microinsurance for Maize Farmers in Burkina Faso: Access and Agriculture Performance in Dandé Village,' 115-127.

59 Sonia Akter et al., 'Exploring The Feasibility of Private Micro Flood Insurance Provision in Bangladesh,' Disasters, vol. 35/2 (2011): 297. 
Díaz Nieto et al., ${ }^{60}$ Daniel J. Clarke dan Dermot Grenham. ${ }^{61}$ Takaful banjir dan takaful cuaca yang dibincangkan adalah berbentuk perlindungan harta yang musnah yang melibatkan tempat tinggal dan pekerjaan yang melibatkan petani. Kelima, takaful pengangguran juga termasuk dalam perlindungan yang boleh ditawarkan di bawah takaful mikro seperti yang dinyatakan oleh Vishal Pinto, ${ }^{62}$ Sonia Akter et al. ${ }^{63}$ Keenam, takaful pencen disebut oleh James Midgley, ${ }^{64}$ Markus Loewe ${ }^{65}$ sebagai skim di bawah takaful mikro kepada warga emas. Oleh itu, berdasarkan kajian literatur mengenai skim takaful kepada warga emas boleh ditawarkan di bawah skim takaful mikro kerana menepati konsep takaful mikro yang dibincangkan oleh sarjana dalam bidang takaful mikro. Skim takaful mikro warga emas juga, merupakan kumpulan yang tidak disasarkan oleh takaful komersial dan takaful sosial. Oleh itu, berdasarkan kajian lapangan yang dilakukan dengan BNM juga turut menyokong takaful mikro ditawarkan kepada warga emas. ${ }^{66}$ Oleh itu, produk takaful mikro relevan untuk ditawarkan kepada warga emas.

\section{SALURAN PENAWARAN SKIM TAKAFUL MIKRO}

Skim takaful mikro boleh ditawarkan melalui pelbagai saluran dan tidak mempunyai kaedah atau saluran tertentu. ${ }^{67}$ Berdasarkan kajian literatur yang dilakukan saluran penawaran takaful mikro oleh pengendali takaful memerlukan sokongan atau bantuan daripada kerajaan secara langsung atau

${ }^{60}$ Jacqueline Díaz Nieto et al., 'Weather Indices for Designing Micro-Insurance Products for Small-Holder Farmers in the Tropics,' Weather Indices for MicroInsurance Product, vol. 7/6 (2012): 1-3.

61 Daniel J. Clarke \& Dermot Grenham, 'Microinsurance and Natural Disasters: Challenges and Options,' S90.

62 Vishal Pinto, 'Role of NGOs in Promoting Micro Health Insurance: A Study with Reference to 'Sampoorna Saraksha' Health Insurance Scheme by SKDRDP, Mangalore (India),' 253.

63 Sonia Akter et al., 'Exploring The Feasibility of Private Micro Flood Insurance Provision in Bangladesh,' 297.

64 James Midgley, 'Social Protection and the Elderly in the Developing World: Mutual Aid, Micro-Insurance and the State,' 156.

65 Markus Loewe, 'New Avenues to be Opened for Social Protection in the Arab World: The Case of Egypt,' 13.

66 Responden 4 (Penganalisis, Jabatan Perbankan Islam dan Takaful, Bank Negara Malaysia), dalam temu bual beliau bersama penulis pada 15 Februari 2019.

67 Craig Churchill, 'Insuring the Low-Income Market: Challenges and Solutions for Commercial Insurers,' 403. 
tidak langsung. Hal ini turut dinyatakan oleh Rafiza Zuliani dan Asmak Ab Rahman ${ }^{68}$ bahawa kejayaan takaful mikro dapat dilaksanakan dengan mendapat sokongan daripada kerajaan. Institusi yang bekerjasama dengan pengendali takaful swasta atau awam adalah Institusi Kewangan Mikro (MFIs), Komuniti dan NGO. Seiro Ito dan Hisaki Kono ${ }^{69}$ menyatakan takaful mikro melibatkan lima pihak iaitu peserta, pengendali takaful, penyedia penjagaan (hospital), pentadbiran pihak ketiga (the third-party administrator (TPA)) dan NGO/ MFIs. Rebekah Yore dan Joanna Faure Walker ${ }^{70}$ pula menyatakan takaful mikro boleh disampaikan melalui bank, MFIs, pengendali takaful, entiti komersial dan perniagaan. Oscar Joseph Akotey, Kofi A. Osei dan Albert Gemegah ${ }^{71}$ pula menyatakan pengendali takaful boleh bekerjasama dengan organisasi berasaskan komuniti seperti gereja, persatuan peniaga wanita, NGO, MFIs, perkampungan dan bank komuniti dalam menyediakan kos efektif untuk perkhidmatan takaful mikro.

Daniel J. Clarke dan Dermot Grenham ${ }^{72}$ pula menyatakan pengendali takaful perlu mengembangkan cara-cara yang efektif untuk mencapai keperluan asas pelanggan. Contohnya kerjasama masyarakat berasaskan komuniti, organisasi pembiayaan mikro, pengantara lain atau menggunakan perkembangan teknologi seperti peningkatan jaringan luas menggunakan telefon bimbit untuk urusan kewangan. Pengalaman daripada luar negara mencadangkan skim takaful mikro dibentuk berdasarkan Partner Agent Model di mana tugas takaful dibahagikan antara ejen pengedar iaitu NGO, persatuan buruh atau persatuan koperasi dan rakan komersial iaitu sama ada pengendali takaful swasta atau awam. Semua pihak bertanggungjawab melakukan tugas dengan lebih baik. ${ }^{73}$ Pengendali takaful boleh menggunakan infrastruktur sedia ada untuk mengedarkan dan menguruskan produk untuk mengurangkan

68 Rafiza Zuliani \& Asmak Ab Rahman, 'Micro-Takaful in Aceh: Does Society Need It?' dalam New Developments in Islamic Economics, ed. Asmak Ab Rahman (United Kingdom: Emerald Publishing, 2019), 113.

69 Seiro Ito \& Hisaki Kono, 'Why is The Take-up of Microinsurance so Low? Envidence from A Health Insurance Scheme in India,' 78.

70 Rebekah Yore \& Joanna Faure Walker, 'Microinsurance for Disaster Recovery: Business Venture or Humanitarian Intervention?: An Analysis of Potential Success and Failure Factors of Microinsurance Case Studies,' 27.

71 Oscar Joseph Akotey, Kofi A. Osei \& Albert Gemegah, 'The Demand for Micro Insurance in Ghana,' 191.

72 Daniel J. Clarke \& Dermot Grenham, 'Microinsurance and Natural Disasters: Challenges and Options,' S90.

73 Markus Loewe, 'New Avenues to be Opened for Social Protection in the Arab World: The Case of Egypt,' 13. 
kos yang terlibat dalam memperkenalkan produk-produk takaful mikro. Walau bagaimanapun, pengendali takaful perlu bekerjasama dengan organisasi yang boleh dipercayai dan selamat dari segi kewangan. ${ }^{74}$ Penawaran takaful mikro juga perlu dilaksanakan selaras dengan persekitaran sosial, budaya dan keagamaan penduduk untuk mendapat pengiktirafan dan penerimaan daripada kumpulan yang kurang mendapat perlindungan. ${ }^{75}$ Berdasarkan pengumpulan kajian literatur dapat dibahagikan kerjasama pengendali takaful swasta atau awam untuk menawarkan takaful mikro melalui saluran berikut:

\section{Sokongan Kerajaan Secara Tidak Langsung}

\section{a) Institusi Kewangan Mikro (MFIs)}

Craig Churchill ${ }^{76}$ menyatakan bahawa skim takaful mikro boleh didapati daripada MFIs secara mandatori. Sekiranya pelanggan mengambil pinjaman perlu membayar yuran tambahan sebagai premium untuk perlindungan takaful. Hal ini, merupakan kelebihan MFIs untuk mengurangkan risiko kerugian pinjaman. Joseph Oscar Aktey dan Charles K.D Adjasi ${ }^{77}$ menggariskan keperluan untuk memajukan mikro kredit dan takaful mikro kepada golongan miskin sebagai pakej bersama dan bukan produk berasingan. Dalam kajian Mohammad Saleh Torkestani dan Pari Ahadi ${ }^{78}$ membuat penilaian MFIs di Iran mempunyai kesediaan yang cukup untuk memperkenalkan takaful mikro sebagai produk baharu dengan kerjasama masyarakat Iran mendapat skor sebanyak 84.67 dan kerajaan sebanyak 88.00. Kedua-dua kerjasama ini penting yang akan menjadi kekuatan dalam penawaran takaful mikro. Vishal Pinto $^{79}$ menyatakan takaful mikro ini ditawarkan disebabkan pematuhan

74 Daniel J. Clarke \& Dermot Grenham, 'Microinsurance and Natural Disasters: Challenges and Options,' S90-S91.

75 Shuaibu Mukhtar, 'Insuring the Uninsurable for Poverty Alleviation in Nigeria: What Micro-Insurance can do?,' 375.

76 Craig Churchill, 'Trying To Understand The Demand for Microinsurance,' 381.

77 Joseph Oscar Aktey \& Charles K.D. Adjasi, 'Dose Microcredit Increase Household Welfare in the Absence of Microinsurance?' 390.

78 Mohammad Saleh Torkestani \& Pari Ahadi, 'Readiness Assessment of Islamic Micro-Finance Institution to Implement Micro-Insurance Concept (Case of Iran), International Journal of Islamic and Middle Eastern Finance and Management, vol. 1/3 (2008): 259.

79 Vishal Pinto, 'Role of NGOs in Promoting Micro Health Insurance: A Study with Reference to 'Sampoorna Saraksha' Health Insurance Scheme by SKDRDP, Mangalore (India),' 252. 
terhadap pengawal selia atau dipanggil Insurance Regulatory and Development Authority of India (IRDA). Pada mulanya, syarikat-syarikat insurans enggan menawarkan produk kepada golongan miskin kerana tidak menguntungkan, inisiatif ini turut diambil oleh institusi kewangan mikro atau "microfinance institutions (MFIs)" yang juga menawarkan mikro kredit kepada golongan miskin. ${ }^{80}$ Oleh itu, penawaran skim takaful kesihatan mikro ini mendapat sambutan sangat baik walaupun belum melakukan kerjasama dengan agensi kerajaan secara langsung. ${ }^{81}$

\section{b) Komuniti}

Di Nepal, takaful kesihatan berasaskan komuniti (CBHI) telah dilancarkan di Dhading dan Banke pada tahun 2011. ${ }^{82}$ Di India, Pradeep Panda, Arpita Chakrorty dan David M.Dror ${ }^{83}$ menyatakan penawaran takaful mikro berasaskan komuniti dengan kerjasama NGO dapat membantu meningkatkan kefahaman terhadap takaful kepada golongan miskin luar Bandar. Oscar Joseph Akotey, Kofi A. Osei dan Albert Gemegah ${ }^{84}$ pula menyatakan pengendali takaful boleh bekerjasama dengan organisasi berasaskan komuniti seperti gereja, persatuan peniaga wanita, perkampungan dan bank komuniti dalam menyediakan kos efektif untuk perkhidmatan takaful mikro.

\section{c) Badan Bukan Kerajaan (NGO)}

Markus Loewe menyatakan bahawa skim takaful mikro seharusnya dipertimbangkan sebagai perkongsian antara NGO dan pengendali takaful komersial atau kerajaan. ${ }^{85}$ Di Mesir, kos urusniaga bagi takaful mikro adalah

80 Vishal Pinto, 'Role of NGOs in Promoting Micro Health Insurance: A Study with Reference to 'Sampoorna Saraksha' Health Insurance Scheme by SKDRDP, Mangalore (India),' 252.

81 Vishal Pinto, 'Role of NGOs in Promoting Micro Health Insurance: A Study with Reference to 'Sampoorna Saraksha' Health Insurance Scheme by SKDRDP, Mangalore (India),' 260.

82 David M. Dror et al., 'Implementing A Participatory Model of Micro Health Insurance among Rural Poor with Evidence from Nepal,' 280.

83 Pradeep Panda, Arpita Chakrorty \& David M.Dror, 'Building Awareness to Health Insurance Among the Target Population of Community-based Health Insurance Scheme in Rural India,' Tropical Medicine and International Health, vol. 20/8 (2015): 1093-1103.

84 Oscar Joseph Akotey, Kofi A. Osei \& Albert Gemegah, 'The Demand for Micro Insurance in Ghana,' 191.

85 Markus Loewe, 'New Avenues to be Opened for Social Protection in the Arab World: The Case of Egypt,' 3. 
rendah kerana NGO beroperasi dengan kumpulan berpendapatan rendah. Hubungan di antara NGO dengan peserta dapat mengenal pasti risiko yang dihadapi dan maklumat yang tepat. Selain itu, pekerja NGO biasanya dibayar dengan gaji yang rendah dan kos pentadbiran juga sangat rendah. ${ }^{86}$

\section{d) Institusi Kewangan Mikro (MFIs) dan Badan Bukan Kerajaan (NGO)}

Industri swasta telah terlibat untuk menawarkan produk takaful am, takaful kesihatan dan lain-lain takaful mikro. Selain daripada industri swasta, terdapat MFIs dan NGO yang telah tampil menawarkan perkhidmatan takaful mikro kepada pelanggan di bawah institusi mereka ${ }^{87}$ Peranan MFIs dan NGO adalah mendidik dan memasarkan skim takaful mikro untuk golongan miskin. ${ }^{88} \mathrm{Hal}$ ini turut disokong oleh Oscar Joseph Akotey, Kofi A. Osei dan Albert Gemegah pula menyatakan pengendali takaful boleh bekerjasama dengan organisasi seperti NGO dan MFIs. ${ }^{89}$

\section{Sokongan Kerajaan Secara Langsung}

\section{a) Kerajaan dan Swasta}

Kerajaan menyelesaikan dan mengatasi perbezaan yang terdapat antara penyediaan mikro kredit yang tidak berasaskan keuntungan dan pengendali takaful swasta berasaskan keuntungan. Kedua-dua elemen diperlukan untuk membina kecekapan semua pihak supaya dapat membangunkan pasaran takaful mikro melalui Public-Private Partnership. ${ }^{90}$ Takaful mikro bencana dapat memainkan peranan yang bermanfaat sebagai sebahagian strategi pengurusan risiko kepada orang miskin. Walau bagaimanapun, untuk merealisasikan

\footnotetext{
86 Markus Loewe, 'New Avenues to be Opened for Social Protection in the Arab World: The Case of Egypt,' 12.

87 Vishal Pinto, 'Role of NGOs in Promoting Micro Health Insurance: A Study with Reference to 'Sampoorna Saraksha' Health Insurance Scheme by SKDRDP, Mangalore (India),' 252.

88 Seiro Ito \& Hisaki Kono, 'Why is The Take-up of Microinsurance so Low? Envidence from A Health Insurance Scheme in India,' 79.

89 Oscar Joseph Akotey, Kofi A. Osei \& Albert Gemegah, 'The Demand for Micro Insurance in Ghana,' 191.

90 Sonia Akter et al., 'Exploring The Feasibility of Private Micro Flood Insurance Provision in Bangladesh,' 305.
} 
potensi ini memerlukan sokongan dan koordinasi daripada kerajaan dan sektor swasta. ${ }^{91}$

\section{b) Kerajaan, Swasta dan Badan Bukan Kerajaan (NGO)}

Kajian ini mencadangkan pengendali takaful swasta bekerjasama dengan NGO dan kerajaan dalam penyediaan takaful mikro sebagai strategi mengurangkan kemiskinan secara berkesan. Tambahan, isu-isu penyediaan takaful kepada kumpulan berpendapatan rendah tidak mampu ditangani oleh pihak swasta sahaja. Oleh itu, kejayaan utama dalam menangani keperluan penduduk memerlukan kerjasama daripada semua pihak iaitu swasta, NGO dan kerajaan. ${ }^{92}$ Takaful mikro untuk kesihatan menjadi instrumen penting dalam strategi kesihatan awam negara kepada golongan miskin yang diperolehi daripada kemudahan awam, swasta atau NGO.$^{93}$ Di Mesir, pekerja di sektor tidak formal diberi pilihan untuk mendaftar dalam skim NGO atau skim awam yang keduaduanya mendapat bantuan daripada perbendaharaan awam. Hal ini, membawa kepada kerajaan bekerjasama antara NGO dan pengendali takaful komersial. ${ }^{94}$

Oleh itu, saluran penawaran takaful mikro boleh dilakukan dengan sokongan dan bantuan kerajaan secara langsung dan tidak langsung melalui MFIs, komuniti, NGO, swasta dan kerajaan yang relevan. Secara ringkasnya, takaful mikro relevan untuk bekerjasama dengan JKM berdasarkan saluran penawaran yang boleh dilaksanakan dengan kerjasama komuniti, pusat jagaan warga emas NGO dan swasta yang telah pun melakukan kerjasama dengan JKM. Oleh itu, kajian ini akan mengenal pasti saluran penawaran takaful mikro kepada warga emas di bawah JKM.

\section{METODOLOGI KAJIAN}

Kajian ini menggunakan kaedah kualitatif yang melibatkan temu bual dan dokumentasi. Temu bual yang telah dijalankan melibatkan JKM, pengendali

91 Daniel J. Clarke \& Dermot Grenham, 'Microinsurance and Natural Disasters: Challenges and Options,' S90.

92 Christian Biener, Martin Eling \& Joan T.Schmit, 'Regulation in Microinsurance Markets: Principles, Practice and Directions for Future Development,' World Development, vol. 58 (2014): 28.

93 Wendy J. Werner, 'Micro-insurance in Bangladesh: Risk Protection for the Poor?' Journal of Health, Population and Nutrition, vol. 27/4 (2009): 571.

94 Markus Loewe, 'New Avenues to be Opened for Social Protection in the Arab World: The Case of Egypt,' 13. 
takaful dan BNM. Peserta daripada JKM melibatkan bahagian warga emas, bahagian kebajikan produktif dan bahagian komuniti. Temu bual dengan pengendali takaful pula melibatkan AIA Public Takaful di Jabatan Pemasaran produk, Prudential BSN Takaful di Jabatan Takaful Mikro dan CSR dan Takaful Ikhlas di Jabatan Bancatakaful. Manakala, bagi pihak BNM temu bual dilakukan dengan Jabatan Perbankan Islam dan Takaful. Kaedah temu bual yang digunakan adalah separa berstruktur untuk mendapatkan data dan maklumat yang lebih terperinci daripada para peserta. Kaedah ini banyak membantu penyelidik untuk mendapatkan maklumat berkaitan bentuk-bentuk perkhidmatan di JKM yang telah diberikan kepada warga emas, produkproduk penawaran takaful mikro yang ditawarkan oleh pengendali takaful di bawah inisiatif Perlindungan Tenang dan inisiatif penawaran takaful mikro oleh BNM. Bagi dokumentasi pula dilakukan untuk mengenal pasti konsep takaful mikro dan warga emas melalui buku, jurnal, laporan akhir Institut Penyelidikan Penuaan Malaysia Universiti Putra Malaysia (UPM), kertas kerja persidangan dan laman sesawang. Laman sesawang yang dirujuk adalah JKM bagi mendapatkan maklumat tentang bentuk-bentuk perkhidmatan yang diberikan JKM kepada warga emas. Manakala, laman sesawang Malaysian Takaful Association(MTA), AIA Public Takaful, Prudential BSN Takaful dan Agro Bank dirujuk bagi melihat produk-produk takaful mikro yang ditawarkan oleh pengendali takaful. Kedua-dua kaedah membantu penyelidik memahami lebih lanjut terhadap maklumat yang diperolehi menerusi temu bual dan dokumentasi yang dirujuk oleh penyelidik.

\section{MOTIVASI KAJIAN}

Kajian ini ingin melihat kesesuaian penawaran takaful mikro dengan kerjasama JKM kepada warga emas yang mewakili pihak kerajaan persekutuan, seiring dengan isu peningkatan jangka hayat yang bakal memberi kesan kepada peningkatan bilangan warga emas di negara ini.

\section{BENTUK-BENTUK PERKHIDMATAN JABATAN KEBAJIKAN MASYARAKAT (JKM) KEPADA WARGA EMAS}

Perkhidmatan kepada warga emas di JKM adalah bantuan kewangan, institusi, perkhidmatan berasaskan komuniti dan terdapat lain-lain bantuan seperti jadual berikut: 
Jadual 1: Bentuk-Bentuk Perkhidmatan Kepada Warga Emas

\begin{tabular}{ll}
\hline Bantuan Kewangan & -Bantuan Orang Tua (BOT) \\
& -Pertubuhan Sukarela Kebajikan (PSK) \\
Institusi & -Rumah Seri Kenangan (RSK)-10 Cawangan \\
& -Rumah Ehsan-2 Cawangan \\
Perkhidmatan & -Program Khidmat Bantu di Rumah (Home Help \\
berasaskan & Services)-2,562 petugas \\
Komuniti & -Pusat Aktiviti Warga Emas (PAWE)-88 Cawangan \\
& -Unit Penyayang Warga Emas (UPWE)-9 Unit Kenderaan \\
& -Penjagaan Sementara (Respite Care)-1 cawangan \\
& -Pusat Jagaan Bukan Kerajaan dan Swasta-409 Cawangan \\
Lain-lain Bantuan & -Alat Bantuan \\
& -Pesakit Terlantar dan Kronik \\
\hline
\end{tabular}

Sumber: Maklumat daripada Bahagian Warga Emas, $2018^{95}$

\section{Bantuan Kewangan}

\section{a) Bantuan Orang Tua (BOT)}

BOT yang diberikan RM350 sebulan seorang sebagai saraan hidup kepada warga emas yang memerlukan bantuan supaya terus tinggal dalam komuniti. Kelayakan bantuan, berumur 60 tahun ke atas tiada sumber pendapatan untuk menyara hidup dan tiada keluarga atau mempunyai keluarga yang tidak berkemampuan untuk memberi sumbangan. ${ }^{96}$ Berdasarkan kepada kelayakan berikut terdapat warga emas yang mendapat BOT bermula tahun 2012 hingga 2018 seperti jadual berikut:

95 Responden 1 (Ketua Penolong Pengarah Kanan, Bahagian Warga Emas (Cawangan Perkhidmatan Institusi), Jabatan Kebajikan Masyarakat), dalam temu bual beliau bersama penulis pada 22 November 2018.

96 Portal Rasmi Jabatan Kebajikan Masyarakat, 'Pengenalan,' laman sesawang Jabatan Kebajikan Masyarakat, http://www.jkm.gov.my/jkm/index.php?r=portal/ left\&id=VEpUUXV3THFURkZET mxWNjZpQ1BXdz09, dicapai pada 5 April 2019. 
Jadual 2: Bantuan Orang Tua (BOT) bermula Tahun 2012-2018

\begin{tabular}{ccc}
\hline Tahun & Bil. Kes & RM \\
\hline 2012 & 152,138 & $519,297,450$ \\
2013 & 142,124 & $540,081,900$ \\
2014 & 142,032 & $500,401,902$ \\
2015 & 141,493 & $497,506,634$ \\
2016 & 133,352 & $489,443,140$ \\
2017 & 134,614 & $324,467,110$ \\
2018 (Jun) & 136,036 & $324,467,110$ \\
\hline Jumlah & $\mathbf{9 8 1 , 7 8 9}$ & $\mathbf{3 , 3 7 3 , 4 2 3 , 2 1 6}$
\end{tabular}

Sumber: Maklumat daripada Bahagian Kebajikan Produktif, 2019.97

\section{b) Bantuan Kewangan Pertubuhan Sukarela Kebajikan (PSK)}

Tujuan bantuan ini adalah untuk membantu menampung keperluan PSK dan mengurangkan kemasukan klien ke institusi. ${ }^{98}$

Jadual 3: Belanjawan Pertubuhan Sukarela Kebajikan (PSK) mengikut tahun

\begin{tabular}{cc}
\hline Tahun & Belanjawan \\
\hline 2013 & $28,071,181.26$ \\
2014 & $27,627,482.20$ \\
2015 & $27,720,726.00$ \\
2016 & $23,047,688.00$ \\
2017 & $23,431,981.00$ \\
2018 & $18,534,442.80$ \\
\hline
\end{tabular}

Sumber: Maklumat daripada Bahagian Komuniti. ${ }^{99}$

97 Responden 2 (Penolong Pengarah, Bahagian Kebajikan Produktif, Jabatan Kebajikan Masyarakat), dalam temu bual beliau bersama penulis pada 22 November 2018.

98 Responden 3 (Ketua Penolong Pengarah, Bahagian Komuniti (Cawangan Pertubuhan Sukarela Kebajikan), Jabatan Kebajikan Masyarakat), dalam temu bual beliau bersama penulis pada 13 Februari 2019.

99 Responden 3 (Ketua Penolong Pengarah, Bahagian Komuniti (Cawangan Pertubuhan Sukarela Kebajikan), Jabatan Kebajikan Masyarakat), dalam temu bual beliau bersama penulis pada 13 Februari 2019. 
Asas pertimbangan pemberian bantuan kewangan kerajaan kepada PSK:100

a) Berdaftar dengan Pendaftar Pertubuhan di bawah Akta Pertubuhan 1966 atau di bawah Undang-Undang Tubuh lain.

b) Pertubuhan bertaraf tempatan.

c) Pertubuhan yang bercorak kebajikan (welfare-related) yang mengendalikan program berbentuk pencegahan, pemulihan, penjagaan, perlindungan dan pembangunan bagi kumpulan sasar di bawah tanggungjawab dan fungsi Jabatan

d) Berdaftar di bawah Akta Pusat Jagaan 1993 bagi yang mengendalikan program institusi berkediaman atau Pusat Jagaan Harian.

e) Tidak mempunyai sumber kewangan yang mencukupi untuk menampung perjalanan program.

f) Mempunyai perancangan masa depan untuk menanggung kos pembiayaan program selepas tamat tempoh penerimaan bantuan.

g) Telah beroperasi sekurang-kurangnya tiga tahun bagi PSK baru.

\section{Perkhidmatan kepada warga emas yang berbentuk institusi}

Perkhidmatan institusi terbahagi kepada dua, iaitu Rumah Ehsan (RE) dan Rumah Seri Kenangan (RSK)

Jadual 4: Rumah Ehsan (RE) dan Rumah Seri Kenangan (RSK)

\begin{tabular}{|c|c|c|}
\hline Institusi Kebajikan & Rumah Ehsan (RE) & $\begin{array}{c}\text { Rumah Seri Kenangan } \\
\text { (RSK) }\end{array}$ \\
\hline Penerangan & $\begin{array}{l}\text { RE ditubuhkan untuk } \\
\text { memberi jagaan, rawatan dan } \\
\text { perlindungan kepada warga } \\
\text { emas yang uzur, daif dan tidak } \\
\text { berwaris agar dapat terus hidup } \\
\text { dalam suasana yang selesa dan } \\
\text { tenteram. }\end{array}$ & $\begin{array}{l}\text { RSK ditubuhkan untuk } \\
\text { memberi jagaan dan } \\
\text { perlindungan kepada } \\
\text { warga emas yang daif demi } \\
\text { menjamin kesejahteraan dan } \\
\text { kualiti hidup mereka. }\end{array}$ \\
\hline
\end{tabular}
tenteram.

$\overline{100}$ Responden 3 (Ketua Penolong Pengarah, Bahagian Komuniti (Cawangan Pertubuhan Sukarela Kebajikan), Jabatan Kebajikan Masyarakat), dalam temu bual beliau bersama penulis pada 13 Februari 2019. 


\begin{tabular}{|c|c|c|}
\hline Institusi Kebajikan & Rumah Ehsan (RE) & $\begin{array}{c}\text { Rumah Seri Kenangan } \\
\text { (RSK) }\end{array}$ \\
\hline $\begin{array}{l}\text { Objektif penubuhan/ } \\
\text { Perkhidmatan }\end{array}$ & $\begin{array}{l}\text {-Penjagaan dan perlindungan } \\
\text {-Bimbingan dan kaunseling } \\
\text {-Perkhidmatan fisioterapi } \\
\text {-Bimbingan agama } \\
\text {-Rekreasi dan carapulih kerja } \\
\text {-Rawatan perubatan }\end{array}$ & $\begin{array}{l}\text {-Jagaan dan perlindungan } \\
\text {-Bimbingan dan kaunseling } \\
\text {-Aktiviti Rekreasi } \\
\text {-Rawatan perubatan } \\
\text {-Terapi cara kerja } \\
\text {-Fisioterapi }\end{array}$ \\
\hline Cawangan & $\begin{array}{l}\text { RE Dungun, Terengganu. } \\
\text { RE Kuala Kubu Bahru, Selangor. }\end{array}$ & $\begin{array}{l}\text { RSK Kangar, Perlis. } \\
\text { RSK Bedong, Kedah. } \\
\text { RSK Taiping, Perak. } \\
\text { RSK Ulu Kinta, Perak. } \\
\text { RSK Sri Iskandar, Perak } \\
\text { RSK Cheras, Selangor. } \\
\text { RSK Seremban, Negeri } \\
\text { Sembilan. } \\
\text { RSK Cheng, Melaka. } \\
\text { RSK Johor Bahru, Johor. } \\
\text { RSK Kemumin, Kelantan. }\end{array}$ \\
\hline Syarat Kemasukan & $\begin{array}{l}\text {-Warganegara Malaysia } \\
\text {-Tidak berupaya mengurus diri } \\
\text { sendiri } \\
\text {-Tidak mempunyai waris/ } \\
\text { penjaga } \\
\text {-Tidak menghidap penyakit } \\
\text { berjangkit } \\
\text {-Tidak ada sumber pendapatan/ } \\
\text { tidak mampu menyara diri } \\
\text { sendiri pegawai } \\
\text {-Disahkan oleh pebagai } \\
\text { perubatan kerajaan san sat } \\
\text { penyakit melarat }\end{array}$ & $\begin{array}{l}\text {-Warganegara } \\
\text {-Berumur } 60 \text { tahun ke atas } \\
\text {-Tidak ada sumber } \\
\text { pendapatan / tidak mampu } \\
\text { menyara diri sendiri } \\
\text {-Tidak menghidap penyakit } \\
\text { yang berjangkit } \\
\text {-Tidak mempunyai sanak } \\
\text { saudara /waris } \\
\text {-Tidak mempunyai tempat } \\
\text { tinggal yang tetap } \\
\text {-Berupaya mengurus diri } \\
\text { sendiri }\end{array}$ \\
\hline Kaedah Kemasukan & $\begin{array}{l}\text { Permohonan kemasukan adalah } \\
\text { secara sukarela mengikut } \\
\text { Kaedah-Kaedah Pengurusan } \\
\text { Rumah-Rumah Sakit Melarat } \\
\text { 1978. }\end{array}$ & $\begin{array}{l}\text {-Sukarela: permohonan } \\
\text { kemasukan akan diproses } \\
\text { mengikut Kaedah-Kaedah } \\
\text { Bagi Pengurusan Rumah } \\
\text { Orang-Orang Tua } 1983 \\
\text {-Perintah Mahkamah: } \\
\text { Kemasukan adalah melalui } \\
\text { perintah Mahkamah } \\
\text { mengikut peruntukan Akta } \\
\text { Orang-Orang Papa } 1977\end{array}$ \\
\hline
\end{tabular}




\begin{tabular}{lll}
\hline Institusi Kebajikan & \multicolumn{1}{c}{ Rumah Ehsan (RE) } & \multicolumn{1}{c}{$\begin{array}{c}\text { Rumah Seri Kenangan } \\
\text { (RSK) }\end{array}$} \\
\hline Belanjawan & Tahun 2018 RM 8,162,016.00 & Tahun 2018 RM \\
& Tahun 2017 RM 8,089,380.00 & $35,415,781.00$ \\
& Tahun 2016 RM 6,528,192.00 & Tahun 2017 RM \\
& Tahun 2015 RM 6,106,627.50 & $34,923,465.00$ \\
& & Tahun 2016 RM \\
& & $31,016,933.57$ \\
& Tahun 2015 RM \\
& $26,276,525.38$ \\
\hline
\end{tabular}

Sumber: Maklumat daripada Bahagian Warga Emas ${ }^{101}$ Bahagian Komuniti ${ }^{102}$ dan laman sesawang JKM. ${ }^{103}$

\section{Perkhidmatan Berasaskan Komuniti}

Terdapat lima perkhidmatan yang berasaskan komuniti di bawah JKM:

Jadual 5: Perkhidmatan Berasaskan Komuniti

\begin{tabular}{ll}
\hline \multicolumn{1}{c}{ Perkhidmatan } & \multicolumn{1}{c}{ Tujuan } \\
\hline 1. Program Khidmat Bantu di & Penjagaan kepada warga emas yang tinggal bersendirian atau \\
Rumah (Home Help Services) & bersama keluarga tetapi memerlukan sokongan sosial, lemah \\
2,562 petugas & dan daif. Inovasi sosial dalam meningkatkan kesejahteraan \\
& warga emas. Dilaksanakan dengan kerjasama strategi bersama \\
& PSK. Antara perkhidmatan yang diberikan ialah teman berbual, \\
& membersihkan rumah, membeli barangan keperluan dan \\
& meneman ke hospital.
\end{tabular}

Belanjawan: tahun 2013 RM2.4 juta ,tahun 2014 RM2.6 juta, tahun 2015 RM3 juta, tahun 2016 RM6 juta, tahun 2017 RM4 juta, tahun 2018 RM6.3 juta.

Catatan: manfaat program kepada klien warga emas seramai 7,135 orang dan OKU 1,859 orang

101 Responden 1 (Ketua Penolong Pengarah Kanan, Bahagian Warga Emas (Cawangan Perkhidmatan Institusi), Jabatan Kebajikan Masyarakat), dalam temu bual beliau bersama penulis pada 22 November 2018 .

102 Responden 3 (Ketua Penolong Pengarah, Bahagian Komuniti (Cawangan Pertubuhan Sukarela Kebajikan), Jabatan Kebajikan Masyarakat), dalam temu bual beliau bersama penulis pada 13 Februari 2019.

103 Laman sesawang Jabatan Kebajikan Masyarakat (JKM), 'Rumah Ehsan’, Laman sesawang Jabatan Kebajikan Masyarakat (JKM), dicapai pada 14 April 2019; Jabatan Kebajikan Masyarat (JKM), 'Rumah Seri Kenangan (RSK),' laman sesawang Jabatan Kebajikan Masyarakat (JKM), dicapai pada 13 Februari 2019. 
Adakah Relevan Penawaran Takaful Mikro kepada Warga Emas bersama Jabatan Kebajikan Masyarakat (JKM)?

\begin{tabular}{ll}
\hline \multicolumn{1}{c}{ Perkhidmatan } & \multicolumn{1}{c}{ Tujuan } \\
\hline 2. Pusat Aktiviti Warga Emas & -Meningkatkan kualiti hidup warga emas selari dengan konsep \\
(PAWE) & warga emas aktif dan produktif. \\
88 cawangan & -Merupakan program sokongan sosial di peringkat komuniti \\
& yang bertujuan membantu warga emas berinteraksi dengan \\
& rakan sebaya, ahli keluarga dan masyarakat setempat.
\end{tabular}

Catatan belanjawan: perkhidmatan ini diurus oleh NGO, peruntukan pengoperasian PAWE sebanyak RM33,000 setahun bagi setiap PAWE.

3. Unit Penyayang Warga Emas -Menyediakan perkhidmatan dan kemudahan pengangkutan (UPWE)

9 unit kenderaan kepada warga emas mendapatkan pemeriksaan dan rawatan kesihatan di hospital/ klinik termasuk urusan keperluan sosial warga emas.

-Pelaksanaan oleh PSK dan dipantau oleh JKM.

Catatan belanjawan: kenderaan diurus oleh NGO dengan pemantauan JKM.

4. Penjagaan Sementara

(Respite Care)

1 Cawangan
Perkhidmatan alternatif kepada waris/penjaga untuk menempatkan secara sementara warga emas dalam jagaannya di institusi bagi suatu tempoh tertentu, disebabkan tuntutan tugas di luar kawasan atau negara, atau apa-apa sebab yang memerlukan warga emas ditempatkan di institusi dengan jaminan keselamatan.

Catatan belanjawan: Kos dan caj dikenakan kepada warga emas yang tinggal secara sementara.

5. Pusat Jagaan

409 Cawangan
-Terdapat 409 pusat jagaan warga emas yang berdaftar dengan JKM.

-Pusat Jagaan ini juga boleh memohon bantuan daripada JKM melalui geran-geran yang ditawarkan Bahagian PSK seperti geran pentadbiran, geran rangsum, geran pembaikan dan geran perkapita.

Catatan belanjawan: Tiada peruntukan khusus diberikan kepada Pusat Jagaan yang berdaftar dengan pihak JKM. Namun, pusat jagaan boleh membuat permohonan untuk mendapatkan geran mengikut kelulusan dan syarat yang ditetapkan.

Sumber: Maklumat daripada Bahagian Warga Emas, ${ }^{104}$ Bahagian Komuniti, ${ }^{105}$ Bahagian Kebajikan Produktif, ${ }^{106}$ dan laman sesawang JKM

104 Responden 1 (Ketua Penolong Pengarah Kanan, Bahagian Warga Emas (Cawangan Perkhidmatan Institusi), Jabatan Kebajikan Masyarakat), dalam temu bual beliau bersama penulis pada 22 November 2018.

105 Responden 3 (Ketua Penolong Pengarah, Bahagian Komuniti (Cawangan Pertubuhan Sukarela Kebajikan), Jabatan Kebajikan Masyarakat), dalam temu bual beliau bersama penulis pada 13 Februari 2019.

106 Responden 2 (Penolong Pengarah, Bahagian Kebajikan Produktif, Jabatan Kebajikan Masyarakat), dalam temu bual beliau bersama penulis pada 22 November 2018. 


\section{Lain-lain bantuan}

\section{a) Bantuan Alat Tiruan}

Membantu Warga Emas OKU yang tidak berkemampuan untuk membeli peralatan. ${ }^{107}$ Bantuan Alat Tiruan/Alat Sokongan (BAT/AS), bagi membantu warga emas yang OKU dan tidak berkemampuan untuk membeli peralatan seperti kaki palsu, tangan palsu, tongkat tangan/ketiak, kerusi roda, alat pendengaran, cermin mata khas, kasut khas dan peralatan lain yang disyorkan oleh doktor atau pakar perubatan. Hal ini, bagi membolehkan warga emas meningkatkan keupayaan dan seterusnya menjalani kehidupan tanpa sepenuhnya bergantung kepada orang lain. Kadar bantuan adalah nilai sebenar peralatan yang dicadangkan oleh doktor atau pakar perubatan. ${ }^{108}$

\section{b) Bantuan Pesakit Kronik Terlantar (BPT)}

Tujuan bantuan adalah bagi membantu mengurangkan bebanan perbelanjaan keluarga penjaga termasuk anak yang menjaga ibu atau bapa pesakit kronik terlantar. Selain itu, meningkatkan kualiti hidup pesakit terlantar dengan terus tinggal bersama keluarga dan mengurangkan kemasukan/penempatan ke institusi. ${ }^{109}$ Syarat kelayakan adalah pemohon merupakan penjaga kepada pesakit terlantar secara sepenuh masa, berpendapatan isi rumah tidak melebihi RM3,000 sebulan dan merupakan keluarga yang tidak berkemampuan. Kadar bantuan adalah sebanyak RM350 sebulan. ${ }^{110}$

Berdasarkan keempat-empat bentuk perkhidmatan yang diberikan kepada warga emas objektif bentuk-bentuk perkhidmatan yang diberikan secara menyeluruh adalah bagi menggalakkan warga emas hidup berdikari dan

107 Responden 1 (Ketua Penolong Pengarah Kanan, Bahagian Warga Emas (Cawangan Perkhidmatan Institusi), Jabatan Kebajikan Masyarakat), dalam temu bual beliau bersama penulis pada 22 November 2018.

108 Portal Rasmi Jabatan Kebajikan Masyarakat, 'Pengenalan.'

109 Responden 1 (Ketua Penolong Pengarah Kanan, Bahagian Warga Emas (Cawangan Perkhidmatan Institusi), Jabatan Kebajikan Masyarakat), dalam temu bual beliau bersama penulis pada 22 November 2018 .

110 Responden 1 (Ketua Penolong Pengarah Kanan, Bahagian Warga Emas (Cawangan Perkhidmatan Institusi), Jabatan Kebajikan Masyarakat), dalam temu bual beliau bersama penulis pada 22 November 2018; Responden 2 (Penolong Pengarah, Bahagian Kebajikan Produktif, Jabatan Kebajikan Masyarakat), dalam temu bual beliau bersama penulis pada 22 November 2018. 
memperkasakan perkhidmatan berasaskan komuniti agar dapat mengurangkan kemasukan warga emas ke institusi (deinstitusinalization) ${ }^{111}$ yang akan menyebabkan bebanan kewangan yang tinggi kepada kerajaan untuk menampung kos tersebut. ${ }^{12}$ Namun, tidak dinafikan terdapat kes-kes tertentu yang menyebabkan warga emas perlu tinggal di institusi yang disediakan oleh pihak kerajaan.

\section{TAKAFUL MIKRO DAN PERLINDUNGAN TENANG}

BNM dengan kerjasama pengendali takaful telah melakukan inisiatif untuk menawarkan takaful mikro di bawah Perlindungan Tenang. Berikut merupakan kelebihan penawaran produk takaful mikro yang menepati Perlindungan Tenang. ${ }^{113}$

a) Berpatutan (affordable): Sumbangan yang berpatutan dan boleh diperbaharui setiap tahun.

b) Ringkas (simple): Sijil penyertaan takaful ringkas dan mudah untuk difahami.

c) Senang untuk menyertai (easy to purchase/participate): Penyertaan adalah dalam talian secara online atau ejen. Penyertaan juga boleh didapati di cawangan bank terpilih dan telefon mudah alih.

d) Proses tuntutan yang mudah (easy claims process): Tuntutan dengan dokumentasi lengkap akan dibayar dalam tempoh lima hari bekerja.

Terdapat tiga pengendali takaful yang telah mengambil bahagian dalam penawaran takaful mikro dan menepati Perlindungan Tenang iaitu AIA Public Takaful, Prudential BSN Takaful dan Takaful Ikhlas. ${ }^{114}$ BagiAIA Public Takaful

$\overline{111}$ Responden 2 (Penolong Pengarah, Bahagian Kebajikan Produktif, Jabatan Kebajikan Masyarakat), dalam temu bual beliau bersama penulis pada 22 November 2018.

112 Kementerian Kesihatan Malaysia (KKM), 'Warga Emas Terabai,' laman sesawang Portal Myhealth, http://www.myhealth.gov.my/warga-emas-terabai/, dicapai pada 9 April 2019.

113 Malaysia Takaful Association, 'Perlindungan Tenang.'

114 Responden 4 (Penganalisis, Jabatan Perbankan Islam dan Takaful, Bank Negara Malaysia), dalam temu bual beliau bersama penulis pada 15 Februari 2019. 
menawarkan produk AIA i-Starter Plan, Prudential BSN Takaful menawarkan produk Lindungi dan Takaful Ikhlas menawarkan produk Agro Mabrur-i. ${ }^{115}$

\section{Produk AIA i-Starter Plan}

AIA i-Starter Plan adalah pelan takaful keluarga bertempoh 1 tahun yang menyediakan perlindungan kematian. Pelan ini terbuka kepada individu berumur 16 hingga 55 tahun dan boleh disertai secara talian online, caruman yang perlu dibayar adalah sebanyak RM 40.00 secara tahunan. ${ }^{116}$

Jadual 6: Manfaat dan Jumlah Perlindungan Produk AIA i-Starter Plan

\begin{tabular}{cl}
\hline Manfaat & \multicolumn{1}{c}{ Jumlah Perlindungan* } \\
\hline \multirow{3}{*}{ Kematian } & RM 10,000, RM 15,000, RM 20,000, \\
& RM 25,000, RM 30,000 \\
& *Tertakluk kepada maksimum RM30,000 setiap hayat \\
\hline \multicolumn{2}{c}{ Sumber: Laman sesawang AIA Public Takaful, 2019. ${ }^{117}$}
\end{tabular}

\section{Produk Lindungi}

Pelan Takaful Lindungi adalah satu produk online yang menawarkan perlindungan kematian dan manfaat hilang upaya kekal dan menyeluruh (TPD), 100\% daripada jumlah perlindungan asas akan dibayar apabila berlaku kematian akibat semua jenis punca dan berlaku TPD sebelum umur 70 tahun. Pelan ini layak disertai seawal umur 19 tahun sehingga umur 60 tahun. ${ }^{118}$ Anggaran amaun sumbangan sebanyak RM50 setahun, ${ }^{119}$ amaun sumbangan sebenar adalah tertakluk kepada umur, status kesihatan, amaun perlindungan, pekerjaan (jika berkenaan) dan jantina. ${ }^{120}$ Pembayaran sumbangan sehingga tamat tempoh sijil dan amaun sumbangan akan bertukar apabila umur bertambah. ${ }^{121}$

\footnotetext{
115 Malaysia Takaful Association, 'Perlindungan Tenang.'

116 AIA Public Takaful, 'AIA i-Starter,' laman sesawang AIA Public Takaful, https:// www.aia.com.my/ms/our-products/life-protection/aia-i-starter-plan/faq.html., dicapai pada 5 April 2019.

117 AIA Public Takaful, 'AIA i-Starter.'

118 Prudential BSN Takaful, 'Lindungi,' laman sesawang Prundential BSN Takaful, https:/app.prubsn .com.my/online/project/pruBSN/docs/LI_Brochure_BM.pdf., dicapai pada 5 April 2019.

119 Malaysia Takaful Association, 'Perlindungan Tenang.'

120 Prudential BSN Takaful, 'Lindungi.'

121 Prudential BSN Takaful, 'Lindungi.'
} 
Jadual 7: Manfaat dan Jumlah Perlindungan Produk Lindungi

Manfaat

Jumlah Perlindungan

Kematian/Hilang Upaya Kekal RM20,000 sehingga RM30,000

dan Menyeluruh

Sumber: Laman sesawang Prudential BSN Takaful, 2019. ${ }^{122}$

\section{Produk Agro Mabrur-i}

Pakej perlindungan takaful komprehensif ini meliputi manfaat kematian akibat kemalangan, kematian biasa, hilang keupayaan kekal menyeluruh, badal haji, wakaf dan perbelanjaan kematian serta merta. Kelayakan umur 18 hingga 64 tahun. ${ }^{123}$

Jadual 8: Manfaat dan Jumlah Perlindungan Pelan Terbuka



Sumber: Laman sesawang Agro Bank, $2019^{124}$

122 Prudential BSN Takaful, 'Lindungi.'

123 Agro Bank, 'Agro Mabrur-i,' laman sesawang Agro Bank, https://www.agrobank. com.my/product/agro-mabrur-i/., dicapai pada 6 April 2019.

124 Agro Bank, 'Agro Mabrur-i.' 
Jadual 9: Manfaat dan Jumlah Pelindungan Berkelompok

\begin{tabular}{|c|c|c|}
\hline Manfaat/Pelan & Pelan 1 (RM) & Pelan 2 (RM) \\
\hline $\begin{array}{l}\text { Kematian/Hilang Keupayaan Kekal Menyeluruh } \\
\text { Akibat Penyakit }\end{array}$ & $5,000.00$ & $10,000.00$ \\
\hline $\begin{array}{l}\text { Kematian/Hilang Keupayaan Kekal Menyeluruh } \\
\text { Akibat Kemalangan }\end{array}$ & $10,000.00$ & $15,000.00$ \\
\hline Badal Haji & $3,500.00$ & $3,500.00$ \\
\hline Wakaf & 500.00 & 500.00 \\
\hline Perbelanjaan Kematian Serta Merta & $1,000.00$ & $1,000.00$ \\
\hline Sumbangan Takaful Setahun & 40.00 & 60.00 \\
\hline
\end{tabular}

Sumber: Laman sesawang Agro Bank, 2019. ${ }^{25}$

Ringkasan maklumat bagi ketiga-tiga pelan perlindungan yang menepati perlindungan tenang adalah seperti berikut:

Jadual 10: Pelan Perlindungan yang Menepati Perlindungan Tenang

\begin{tabular}{|c|c|c|c|}
\hline $\begin{array}{l}\text { Logo } \\
\text { Pengendali } \\
\text { Takaful }\end{array}$ & $\begin{array}{l}\text { AIA PUBLIC } \\
\text { TAKAFUL }\end{array}$ & $\frac{\text { PRLDENTLAL BSN }}{\text { TAKAFUL }}$ & \\
\hline Nama Produk & AIA i-stater Plan & Lindungi & Agro Mabrur-i \\
\hline $\begin{array}{l}\text { Saluran } \\
\text { Penyertaan }\end{array}$ & Secara Online & Secara Online & Cawangan Agro Bank \\
\hline $\begin{array}{l}\text { Umur } \\
\text { Kemasukan }\end{array}$ & 16-55 tahun & 19-60 tahun & $\begin{array}{l}\text { 18-64 tahun (bagi yang } \\
\text { berumur } 60 \text { tahun keatas } \\
\text { hanya layak } 1 \text { pelan } \\
\text { sahaja }\end{array}$ \\
\hline $\begin{array}{l}\text { Jumlah } \\
\text { perlindungan }\end{array}$ & $\begin{array}{l}\text { RM10k/RM15k/ } \\
\text { RM20k/ } \\
\text { RM25k/RM30k }\end{array}$ & $\mathrm{RM} 20 \mathrm{k} / 30 \mathrm{k}$ & $\begin{array}{l}\text { RM13k (Plan1)/ } \\
\text { RM26k (Plan 2)/ } \\
\text { RM40k (Plan 3) }\end{array}$ \\
\hline Sumbangan & $\begin{array}{l}\text { Serendah RM39.00 } \\
\text { setahun(tertakluk } \\
\text { kepada umur/jantina) }\end{array}$ & $\begin{array}{l}\text { Serendah RM50 } \\
\text { setahun } \\
\text { (tertakluk kepada } \\
\text { umur, jantina, } \\
\text { status kesihatan dan } \\
\text { pekerjaan) }\end{array}$ & $\begin{array}{l}\text { RM75 (Plan1)/ RM135 } \\
\text { (Pan2)/ } \\
\text { RM195 (Plan3) } \\
\text { Tahunan }\end{array}$ \\
\hline $\begin{array}{l}\text { Logo } \\
\text { Produk }\end{array}$ & AIA i-Starter Plan & Lindungi & AGRO MABRUR-i \\
\hline
\end{tabular}

Sumber: Laman sesawang Malaysia Takaful Association, 2019. ${ }^{126}$

\footnotetext{
125 Agro Bank, 'Agro Mabrur-i.'

126 Malaysia Takaful Association, 'Perlindungan Tenang.'
} 


\section{ANALISIS PENYERTAAN TAKAFUL MIKRO BAGI WARGA EMAS}

Analisis penyertaan warga emas dalam takaful mikro dapat dilihat dari aspek had umur kemasukan, had umur perlindungan, kumpulan sasaran, manfaat, saluran penawaran, warga emas yang tinggal di institusi dan warga emas yang tinggal dalam komuniti dapat dihuraikan seperti berikut:

\section{Had Umur Kemasukan}

Produk Takaful Mikro yang menepati Perlindungan Tenang mempunyai had umur kemasukan tertentu untuk disertai. Ketiga-tiga produk mempunyai had umur kemasukan seperti berikut:

Jadual 11: Had Umur Kemasukan bagi Tiga Produk Takaful Mikro

\begin{tabular}{llc}
\hline Pengendali Takaful & \multicolumn{1}{c}{ Nama Produk } & Had Umur Kemasukan \\
\hline AIA Public Takaful & AIA i-Starter Plan & 16 hingga 55 tahun \\
Prudential BSN Takaful & Lindungi & 19 hingga 60 tahun \\
Takaful Ikhlas & Agro Mabrur-i & 18 hingga 64 tahun \\
\hline
\end{tabular}

Sumber: laman sesawang MTA, AIA Public Takaful, Prudential BSN Takaful dan Takaful Ikhlas

Produk AIA i-Starter Plan menawarkan penyertaan bermula umur 16 sehingga 55 tahun, produk Lindungi menawarkan penyertaan bermula umur bermula 19 sehingga 60 tahun dan produk Agro Mabrur-i menawarkan penyertaan bermula umur 18 sehingga 64 tahun. ${ }^{127}$ Oleh itu, bagi penawaran produk takaful mikro sedia ada di pasaran yang sesuai untuk disertai oleh warga emas hanya produk Lindungi dan Agro Mabrur-i yang ditawarkan oleh Prudential BSN Takaful dan Takaful Ikhlas kerana meletakkan had umur kemasukkan yang relevan untuk disertai oleh warga emas iaitu pada umur 60 tahun dan ke atas.

\section{Had Umur Perlindungan}

Produk Takaful Mikro yang menepati Perlindungan Tenang mempunyai had umur perlindungan tertentu untuk disertai bagi produk ini. Ketiga-tiga produk mempunyai had umur perlindungan seperti berikut:

$\overline{127}$ Malaysia Takaful Association, 'Perlindungan Tenang.' 


\section{Jadual 12: Had Umur Perlindungan bagi Tiga Produk Takaful Mikro}

\begin{tabular}{lll}
\hline \multicolumn{1}{c}{ Pengendali Takaful } & \multicolumn{1}{c}{ Nama Produk } & \multicolumn{1}{c}{ Had Umur Perlindungan } \\
\hline AIA Public Takaful & AIA i-Starter Plan & Perlindungan sehingga umur 55 tahun \\
Prudential BSN Takaful & Lindungi & Perlindungan sehingga umur 70 tahun \\
Takaful Ikhlas & Agro Mabrur-i & Perlindungan sehingga umur 64 tahun \\
\hline
\end{tabular}

Sumber: Laman sesawang MTA, AIA Public Takaful, Prudential BSN

Takaful dan Takaful Ikhlas

Had umur perlindungan bagi produk takaful mikro mempunyai had umur perlindungan sehingga umur 70 tahun iaitu produk Lindungi di bawah Prudential BSN Takaful yang menawarkan had umur perlindungan yang paling tinggi berbanding dengan dua produk lagi, diikuti produk Agro Mabrur-i yang menawarkan had umur perlindungan pada umur 64 tahun dan AIA i-Starter menawarkan had umur perlindungan pada umur 55 tahun. Oleh itu, bagi ketiga-tiga produk hanya produk Lindungi dan Agro Mabrur-i yang melepasi usia warga emas. Berdasarkan jangka hayat yang telah dikeluarkan oleh Jabatan Perangkaan Malaysia, jangka hayat bagi penduduk negara ini telah meningkat pada tahun 2018 adalah 77.6 tahun bagi perempuan dan 72.7 tahun bagi lelaki. ${ }^{128}$ Berikut merupakan jadual jangka hayat penduduk di Malaysia pada tahun 2010-2018.

Jadual 13: Jangka Hayat Penduduk di Malaysia pada tahun 2010-2018

\begin{tabular}{lccccccccc}
\hline Tahun & $\mathbf{2 0 1 0}$ & $\mathbf{2 0 1 1}$ & $\mathbf{2 0 1 2}$ & $\mathbf{2 0 1 3}$ & $\mathbf{2 0 1 4}$ & $\mathbf{2 0 1 5}$ & $\mathbf{2 0 1 6}$ & $\mathbf{2 0 1 7}$ & $\mathbf{2 0 1 8}$ \\
\hline Perempuan & 76.6 & 76.8 & 76.9 & 76.9 & 77.0 & 77.1 & 77.0 & 77.2 & 77.6 \\
Lelaki & 71.9 & 72.1 & 72.2 & 72.3 & 72.4 & 72.5 & 72.1 & 72.3 & 72.7 \\
\hline
\end{tabular}

Sumber: Jabatan Perangkaan Malaysia, 2019

Berdasarkan jadual jangka hayat dapat dijelaskan bahawa golongan tua yang berumur 60 tahun keatas akan hidup dalam lingkungan 12 tahun bagi lelaki dan17 tahun bagi perempuan selepas umur 60 tahun. Demikian itu, bagi warga emas yang ingin mendapatkan perlindungan memerlukan tempoh perlindungan dalam lingkungan 2 tahun bagi lelaki dan 7 tahun bagi perempuan selepas had umur perlindungan maksimum 70 tahun seperti yang ditawarkan produk Lindungi oleh Prudential BSN Takaful.

128 Mohd Uzir Mahidin, 'Jadual Hayat Ringkas, Malaysia, 2015-2017,' laman sesawang Jabatan Perangkaan Malaysia, https://www.dosm.gov.my/v1/index. $\mathrm{php}$ ? $\mathrm{r}=$ column/pdfPrev\&id=bkJYT3pXcDZGbjdiK3pWU0ZmNktoQT09., dicapai pada 6 Mei 2018. 


\section{Manfaat}

Produk takaful mikro yang ditawarkan di pasaran sesuai untuk warga emas sertai adalah produk Lindungi dan Agro Mabrur-i. Bagi produk Lindungi menawarkan manfaat kematian dan hilang keupayaan kekal. ${ }^{129}$ Manakala, Agro Mabrur-i pula, menawarkan manfaat yang sama dengan produk Lindungi dengan tambahan manfaat iaitu badal haji dan wakaf. ${ }^{130}$ Manfaat produk Lindungi boleh dimanfaatkan oleh warga emas bagi manfaat kematian dan hilang keupayaan kekal yang berjumlah RM20,000-30,000. ${ }^{131}$ Manfaat tersebut boleh digunakan untuk kos pengurusan jenazah dan membayar hutang si mati. Manakala, bagi manfaat hilang keupayaan kekal boleh digunakan untuk membeli peralatan kesihatan seperti kaki palsu, tangan palsu, tongkat tangan/ketiak, kerusi roda, alat pendengaran, cermin mata khas, kasut khas dan peralatan lain yang disyorkan oleh doktor atau pakar perubatan.

Bagi Agro Mabrur-i pula, menawarkan manfaat yang sama dengan produk Lindungi dengan tambahan manfaat iaitu badal haji dan wakaf. ${ }^{132}$ Manfaat badal haji akan dilakukan bagi pihak warga emas setelah meninggal dunia bagi yang belum berkesempatan untuk melakukan haji sehingga akhir hayatnya. Begitu juga, dengan manfaat wakaf yang akan dilakukan atas nama si mati yang akan menjadi amal jariah yang memberi pahala berkekalan kepada peserta. Oleh itu, manfaat-manfaat yang ditawarkan produk Lindungi dan Agro Mabrur-i relevan untuk ditawarkan kepada warga emas.

\section{Kumpulan Sasaran}

Kumpulan sasaran takaful mikro yang menepati Perlindungan Tenang mensasarkan golongan miskin dan berpendapatan rendah (B40) dengan bayaran caruman yang rendah mengikut kemampuan kewangan golongan ini dan belum mensasarkan kepada warga emas secara secara khusus.

129 Prudential BSN Takaful, 'Lindungi.'

130 Agro Bank, 'Agro Mabrur-i.'

131 Prudential BSN Takaful, 'Lindungi.'

132 Agro Bank, 'Agro Mabrur-i.' 
Jadual 14: Sasaran Penyertaan Bagi Tiga Produk Takaful Mikro

\begin{tabular}{lllll}
\hline \multicolumn{1}{c}{ Pengendali Takaful } & Nama Produk & \multicolumn{3}{c}{ Sasaran Penyertaan } \\
\hline AIA Public Takaful & AIA i-Starter Plan & $\begin{array}{l}\text { Golongan } \\
\text { (B40) }\end{array}$ & Berpendapatan & Rendah \\
Prudential BSN Takaful & Lindungi & $\begin{array}{l}\text { Golongan } \\
\text { (B40) }\end{array}$ & Berpendapatan Rendah \\
Takaful Ikhlas & Agro Mabrur-i & $\begin{array}{l}\text { Golongan Berpendapatan Rendah } \\
\text { (B40) yang bekerja sebagai petani atau } \\
\text { berurusan dengan Agro Bank }\end{array}$ \\
\hline
\end{tabular}

Sumber: Temu bual AIA Public Takaful, Prudential BSN Takaful dan Takaful Ikhlas

Berdasarkan perbincangan sebelum ini telah dinyatakan bahawa had umur penyertaan, had umur perlindungan dan manfaat relevan dan sesuai untuk disertai oleh warga emas. Namun, penyertaan warga emas tertakluk kepada syarat seperti umur, status kesihatan, amaun perlindungan, pekerjaan (jika berkenaan) dan jantina ${ }^{133}$ kerana produk ini bukan produk yang ditawarkan secara Guarantee Insurance Offer (GIO). ${ }^{134}$ Oleh itu, penyertaan warga emas dalam takaful mikro yang ditawarkan akan terbatas apabila tidak menepati syarat-syarat yang ditetapkan.

\section{Saluran Penawaran}

Saluran penawaran yang ditawarkan oleh takaful mikro adalah dapat dilihat seperti berikut:

Jadual 15: Saluran Penawaran bagi Tiga Produk Takaful Mikro

\begin{tabular}{llc}
\hline \multicolumn{1}{c}{ Pengendali Takaful } & \multicolumn{1}{c}{ Nama Produk } & Saluran Penawaran \\
\hline AIA Public Takaful & AIA i-Starter Plan & Talian secara Online \\
Prudential BSN Takaful & Lindungi & Talian secara Online \\
Takaful Ikhlas & Agro Mabrur-i & Agro Bank \\
\hline
\end{tabular}

Sumber: Laman sesawang MTA, AIA Public Takaful, Prudential BSN Takaful dan Takaful Ikhlas

\footnotetext{
$\overline{133}$ Prudential BSN Takaful, 'Lindungi.'

134 Responden 6 (Ketua, Jabatan Takaful Mikro dan CSR, Prudential BSN Takaful), dalam temu bual beliau bersama penulis pada 15 Mei 2019.
} 
Saluran penawaran takaful mikro bagi AIA i-Starter Plan dan Lindungi adalah melalui talian secara online. Manakala, produk Agro Mabrur-i pula boleh didapati melalui kaunter di Agro Bank. Oleh itu, penawaran takaful mikro kepada warga emas melalui talian secara online kurang relevan untuk disertai oleh warga emas kerana keterbatasan warga emas menggunakan komputer, telefon mudah alih dan internet terutamanya bagi warga emas yang miskin dan berpendapatan rendah terutama yang tinggal di kawasan kampung. Manakala, bagi produk Agro Mabrur-i pula relevan ditawarkan kepada warga emas yang terlibatkan dengan sektor pertanian, perniagaan kecil dan usahawan mikro.

\section{Warga Emas yang Tinggal di Institusi JKM}

Penawaran takaful mikro kepada warga emas yang tinggal di institusi iaitu Rumah Ehsan(RE) dan Rumah Seri Kenangan(RSK) kurang sesuai ditawarkan. Pertama, penyertaan secara individu oleh warga emas yang tinggal di institusi tidak menjadi keperluan kerana warga emas yang tinggal di institusi merupakan kumpulan miskin tegar dan tiada lebihan wang untuk menampung bayaran sumbangan takaful. Tambahan, tiada sebab untuk kumpulan ini mengambil takaful kerana warga emas yang tinggal di institusi tidak mempunyai waris atau telah diabaikan oleh waris untuk mengurus manfaat tersebut. Manfaat yang ditawarkan seperti kematian dan hilang keupayaan kekal juga ditanggung oleh pihak JKM kepada warga emas kumpulan ini.

Kedua, penyertaan secara kumpulan juga sukar untuk dilakukan kerana pihak JKM telah menampung keseluruhan kos warga emas yang tinggal di institusi sepenuhnya. Pihak JKM juga memerlukan kecairan tunai untuk digunakan secara terus bagi menampung keperluan warga emas yang tinggal di institusi. Di samping itu, pihak JKM turut memperuntukkan dana bantuan kewangan untuk mengerakkan sukarelawan dalam komuniti untuk membantu warga emas yang tinggal dalam komuniti terus aktif supaya tidak berlaku peningkatan warga emas ke institusi yang akan memberi kesan kepada peningkatan warga emas dan secara langsung akan menyebabkan kos pengurusan warga emas semakin tinggi apabila warga emas yang tinggal di institusi semakin meningkat.

\section{Warga Emas yang Tinggal dalam Komuniti (bukan Institusi JKM)}

Warga emas yang tinggal dalam komuniti ialah warga emas yang tinggal bersama masyarakat diberi dua bentuk perkhidmatan oleh JKM. Pertama, warga emas menerima bantuan kewangan BOT dan kedua, warga emas yang mendapat perkhidmatan berasaskan komuniti seperti Program Khidmat Bantu 
di Rumah (Home Help Services), Pusat Aktiviti Warga Emas (PAWE), Unit Penyayang Warga Emas (UPWE), Penjagaan Sementara (Respite Care), Pusat Jagaan NGO dan Swasta.

\section{a) Bantuan Kewangan}

Warga emas yang mendapat bantuan BOT sebanyak RM350 sebulan. Dana tersebut sangat di perlukan oleh warga emas kerana kriteria bantuan ini diberikan kepada isi rumah yang miskin iaitu mempunyai pendapatan isi rumah tidak melebihi Pendapatan Garis Kemiskinan (PGK) Purata Miskin Isi Rumah Semasa atau PGK Purata Miskin Per Kapita Semasa. ${ }^{135}$ Keperluan kewangan kumpulan ini juga telah mendorong pihak JKM untuk menambah jumlah bantuan pada tahun 2018 sebanyak RM350 daripada jumlah sebelum ini hanya diberikan sebanyak RM300. Berikut dapat dilihat jumlah BOT yang berlaku penambahan jumlah daripada tahun sebelum 1994 hingga 2018 seperti jadual berikut. ${ }^{136}$

Jadual 16: Jumlah Bantuan Orang Tua (BOT) sebelum tahun 1994 hingga 2018

\begin{tabular}{ccccccc}
\hline Sebelum 1994 & $\mathbf{1 9 9 4}$ & $\mathbf{1 9 9 9}$ & $\mathbf{2 0 0 1}$ & $\mathbf{2 0 0 6}$ & $\mathbf{2 0 0 8}$ & $\mathbf{2 0 1 8}$ \\
\hline RM50 & RM70 & RM100 & RM135 & RM200 & RM300 & RM350 \\
\hline
\end{tabular}

Sumber: Maklumat daripada Bahagian Kebajikan Produktif, 2018. ${ }^{137}$

Berdasarkan kajian yang dijalankan oleh Institut Penyelidikan Penuaan Malaysia Universiti Putra Malaysia (UPM), penerima BOT mengutamakan keperluan makanan menggunakan bantuan yang diterima. Berdasarkan rumusan yang dilakukan walaupun jumlah bantuan yang diberikan sedikit dan tidak mencukupi untuk memenuhi keperluan makanan dan keperluan lain serta aspek ekonomi, tetapi hubungan kekeluargaan, hubungan dengan

$\overline{135}$ Responden 2 (Penolong Pengarah, Bahagian Kebajikan Produktif, Jabatan Kebajikan Masyarakat), dalam temu bual beliau bersama penulis pada 22 November 2018.

136 Responden 2 (Penolong Pengarah, Bahagian Kebajikan Produktif, Jabatan Kebajikan Masyarakat), dalam temu bual beliau bersama penulis pada 22 November 2018.

137 Responden 2 (Penolong Pengarah, Bahagian Kebajikan Produktif, Jabatan Kebajikan Masyarakat), dalam temu bual beliau bersama penulis pada 22 November 2018. 
masyarakat dan keyakinan diri meningkat. ${ }^{138}$ Oleh itu, sukar untuk pihak pengendali takaful mensasarkan kumpulan warga emas yang mendapat BOT untuk menyertai takaful kerana bantuan yang diterima lebih diperlukan untuk keperluan makanan dan keperluan asas lain.

\section{b) Perkhidmatan berasaskan Komuniti}

Warga emas yang tinggal dalam komuniti dan mendapat perkhidmatan daripada JKM seperti Program Khidmat Bantu di Rumah (Home Help Services), Pusat Aktiviti Warga Emas (PAWE), Unit Penyayang Warga Emas (UPWE), Penjagaan Sementara (Respite Care), Pusat Jagaan Warga Emas NGO dan swasta relevan untuk ditawarkan takaful mikro kerana warga emas kumpulan ini merupakan kumpulan yang masih mempunyai waris dan tahap kewangan yang masih baik walaupun terdapat sebahagian warga emas daripada kumpulan ini adalah kumpulan miskin. Namun, warga emas kumpulan ini bukan kumpulan warga emas miskin tegar.

\section{PERBINCANGAN DAN CADANGAN}

Perkhidmatan yang disediakan oleh JKM berbentuk kebajikan kepada warga emas miskin, tidak mempunyai waris atau diabaikan waris untuk tinggal di institusi. Perkhidmatan lain adalah untuk mengelak daripada berlaku peningkatan warga emas ke institusi dengan perkhidmatan seperti PAWE, Program Khidmat Bantu di Rumah. Di samping memberi galakan kepada Pusat Jagaan NGO dan swasta yang turut membantu kerajaan supaya warga emas kekal aktif dan terus kekal tinggal dalam komuniti di bawah bantuan kewangan seperti PSK. Maka, warga emas yang tinggal di institusi sukar untuk menyertai takaful mikro kerana kumpulan ini telah mendapat bantuan sepenuhnya daripada kerajaan. Penyertaan secara kumpulan dengan dana daripada kerajaan juga sukar untuk dilakukan kerana kerajaan mempunyai komitmen dana dengan jumlah keseluruhan belanjawan 2018 dapat dilihat seperti jadual berikut:

138 Institut Penyelidikan Penuaan Malaysia, Universiti Putra Malaysia, Laporan Akhir Kajian Keberkesanan Bantuan Kewangan Jabatan Kebajikan Masyarakat, Kementerian Pembangunan Wanita, Keluarga dan Masyarakat (Putrajaya: Jabatan Kebajikan Masyarakat, 2017), 350. 
Jadual 17: Jumlah Keseluruhan Belanjawan 2018 bagi Perkhidmatan Institusi, Komuniti dan Bantuan Kewangan

\begin{tabular}{|c|c|c|c|}
\hline No. & Perkhidmatan Institusi & Belanjawan 2018 & Catatan \\
\hline 1. & Rumah Ehsan (RE) & RM 8,162,016.00 & 2 Cawangan \\
\hline \multirow[t]{2}{*}{2.} & Rumah Seri Kenangan (RSK) & RM 35,415,781.00 & 10 Cawangan \\
\hline & Jumlah & RM43,577,797.00 & \\
\hline \multicolumn{4}{|c|}{ Perkhidmatan Komuniti } \\
\hline 1. & Program Khidmat Bantu di Rumah & RM 6,300,000.00 & 2,562 petugas \\
\hline \multirow[t]{2}{*}{2.} & Pusat Aktiviti Warga Emas (PAWE) & RM 2,904,000.00 & 88 Cawangan \\
\hline & Jumlah & RM9,204,000.00 & \\
\hline \multicolumn{4}{|c|}{ Bantuan Kewangan } \\
\hline 1. & Bantuan Orang Tua (BOT) & RM $324,467,110.00$ & 136,036 orang \\
\hline \multirow[t]{3}{*}{2.} & Pertubuhan Sukarela Kebajikan (PSK) & RM $18,534,442.80$ & 409 Cawangan \\
\hline & Jumlah & RM343,001,552.80 & \\
\hline & Jumlah Keseluruhan & RM 395,783,349.80 & \\
\hline
\end{tabular}

Sumber: Analisis Penyelidik daripada maklumat yang diperoleh secara dokumen semasa temu bual dengan dengan Bahagian Warga Emas, ${ }^{139}$ Bahagian Komuniti, ${ }^{140}$ Bahagian Kebajikan Produktif. ${ }^{141}$

Berdasarkan jadual, perbelanjaan keseluruhan sebanyak RM395,783,349.80 yang melibatkan perbelanjaan secara langsung yang melibatkan warga emas. Perbelanjaan tertinggi dibelanjakan untuk BOT iaitu sebanyak RM324,467,110.00 yang di terima seramai 136,036 orang warga emas. Kedua tertinggi adalah perbelanjaan RSK iaitu sebanyak RM35,415,781.00 dan seterusnya PSK sebanyak 18,534,442.80, diikuti RE sebanyak RM8,162,016 dan Program Khidmat Bantu di Rumah sebanyak RM 6,300,00. Berikut merupakan belanjawan kerajaan kepada warga emas bagi perkhidmatan institusi, perkhidmatan komuniti dan bantuan kewangan. Oleh itu, bagi

139 Responden 1 (Ketua Penolong Pengarah Kanan, Bahagian Warga Emas (Cawangan Perkhidmatan Institusi), Jabatan Kebajikan Masyarakat), dalam temu bual beliau bersama penulis pada 22 November 2018.

140 Responden 3 (Ketua Penolong Pengarah, Bahagian Komuniti (Cawangan Pertubuhan Sukarela Kebajikan), Jabatan Kebajikan Masyarakat), dalam temu bual beliau bersama penulis pada 13 Februari 2019.

141 Responden 2 (Penolong Pengarah, Bahagian Kebajikan Produktif, Jabatan Kebajikan Masyarakat), dalam temu bual beliau bersama penulis pada 22 November 2018. 
penyertaan secara kumpulan dengan caruman daripada kerajaan juga sukar dilakukan kerana kos perbelanjaan kerajaan lebih utama untuk digunakan dan diberikan kepada warga emas untuk mengerakkan komuniti supaya tidak berlaku peningkatan warga emas ke institusi. Pihak kerajaan juga memerlukan kecairan tunai yang tinggi untuk kegunaan perkhidmatan-perkhidmatan tersebut.

Oleh itu, penyelidik mencadangkan takaful mikro ditawarkan dalam dua bentuk, iaitu takaful mikro komersial dan bukan komersial. Takaful mikro bukan komersial telah pun ditawarkan oleh Prudential BSN Takaful untuk produk Takaful Mikro Jariah ${ }^{142}$ yang diberikan secara percuma kepada kumpulan miskin di bawah senarai eKasih. ${ }^{143}$ Demikian, penawaran takaful mikro kepada warga emas yang tinggal di institusi dan warga emas yang mendapat bantuan BOT boleh ditawarkan berbentuk takaful mikro bukan komersial dengan mendapat dana daripada zakat, wakaf dan CSR sebagai caruman untuk warga emas seperti yang dibincangkan oleh sarjana dalam bidang takaful mikro berkaitan penggunaan dana zakat, wakaf dalam takaful mikro oleh Said Adekunle Mikail, Muhammad Ali Jinnah Ahmad, Salami Saheed Adekunle, ${ }^{144}$ Sheila Nu Nu Htay dan Nur Shazwani Sadzali dan Hanudin Amin ${ }^{145}$ Noor Ashikin Mohd Rom dan Zuriah Abdul Rahman ${ }^{146}$ Haslifah Mohamad Hasim ${ }^{147}$ dan CSR oleh Mohd Rizal Muwazir, Kamaruzaman Noordin dan Azian Madun ${ }^{148}$ dan Sheila $\mathrm{Nu} \mathrm{Nu}$

142 Responden 7 (Pengurus, Jabatan Takaful Mikro dan CSR (Produk), Prudential BSN Takaful), dalam temu bual beliau bersama penulis pada 15 Mei 2019.

143 Responden 8 (Pengurus, Jabatan Takaful Mikro dan CSR (CSR), Prudential BSN Takaful), dalam temu bual beliau bersama penulis pada 15 Mei 2019.

144 Said Adekunle Mikail, Muhammad Ali Jinnah Ahmad \& Salami Saheed Adekunle, 'Utilisation of Zakāh and Waqf Fund in Micro-takāful Models in Malaysia: An Exploratory Study,' ISRA International Journal of Islamic Finance, vol. 9/1 (2017): 104.

145 Sheila Nu Nu Htay, Nur Shazwani Sadzali \& Hanudin Amin, 'An Analysis of the Viability of Micro Health Takaful in Malaysia,' 63.

146 Noor Ashikin Mohd Rom \& Zuriah Abdul Rahman, 'Financial Protection for the Poor in Malaysia: Role of Zakah and Micro-takaful,' Journal of King Abdulaziz University, Islamic Economic, vol. 25/1 (2012): 136.

147 Haslifah Mohamad Hasim, 'Developing a Conceptual Framework of Microtakaful as A Strategy towards Poverty Alleviation,' Journal of Economics and Sustainable Development, vol. 5/28 (2014): 2-3.

148 Mohd Rizal Muwazir, Kamaruzaman Noordin \& Azian Madun, 'A Preliminary Study of Social Responsibility of Islamic Insurance Companies in Malaysia,' (Paper presented, International Conference on Art, Economics and Management (ICAEM'14), Dubai, 22-23 Mac 2014), 104. 
Htay dan Nur Shazwani Sadzali dan Hanudin Amin. ${ }^{149}$ Manakala, bagi warga emas yang tinggal dalam komuniti boleh ditawarkan takaful mikro komersial dengan penambahbaikan produk sedia ada dari aspek saluran penawaran dan mempelbagaikan sasaran penawaran yang dapat dibincangkan seperti berikut:

\section{Cadangan Saluran Penawaran Takaful Mikro kepada Warga Emas di Bawah JKM}

Penawaran takaful mikro kepada warga emas yang tinggal dalam komuniti dapat dilakukan dengan kerjasama komuniti, pusat jagaan warga emas NGO dan swasta yang berdaftar dan telah melakukan kerjasama dengan JKM agar dapat menerapkan kefahaman dan kepentingan takaful mikro kepada warga emas kumpulan ini. Saluran penawaran melalui saluaran ini juga, dapat dilakukan tanpa kos perkhidmatan ejen untuk ditawarkan melalui saluran ini.

\section{Cadangan Mempelbagaikan Sasaran Penawaran Takaful Mikro}

Cadangan mempelbagai sasaran takaful mikro pada masa hadapan bagi produk takaful mikro sedia ada kepada segmen lain seperti warga emas. Hal ini, seiring dengan peningkatan bilangan warga emas di negara ini yang akan memberi kesan kepada keperluan perlindungan kepada kumpulan ini. Oleh itu, cadangan ini membolehkan produk yang ditawarkan lebih sesuai untuk disertai oleh warga emas dari segi umur, status kesihatan, amaun perlindungan, pekerjaan dan jantina. Reka bentuk penawaran produk kepada warga emas dapat dilihat sudah terdapat produk-produk yang ditawarkan kepada warga emas di pasaran seperti Ikhlas Senior Citizen, i-Great Amin dan Hong Leong MSIG i-Kudrat yang meletakkan syarat penyertaan yang lebih sesuai untuk disertai oleh warga emas.

\section{KESIMPULAN}

Penawaran takaful mikro kepada warga emas di bawah JKM terbahagi kepada warga emas yang tinggal di institusi dan dalam komuniti. Penawaran takaful mikro kepada warga emas yang tinggal di institusi dapat ditawarkan melalui skim takaful mikro bukan komersial dengan menggunakan dana daripada zakat, wakaf dan CSR. Bagi penawaran takaful mikro kepada warga emas yang tinggal dalam komuniti pula, takaful mikro berbentuk bukan komersial dapat

149 Sheila Nu Nu Htay, Nur Shazwani Sadzali \& Hanudin Amin, 'An Analysis of the Viability of Micro Health Takaful in Malaysia,' 63. 
ditawarkan kepada warga emas yang layak mendapat bantuan kewangan, iaitu BOT sahaja. Manakala bagi warga emas yang tinggal dalam komuniti boleh ditawarkan takaful mikro komersial kepada kumpulan ini dengan saluran penawaran melalui perkhidmatan komuniti, pusat jagaan warga emas NGO dan swasta yang berdaftar dan telah melakukan kerjasama dengan pihak JKM sebagai saluran penawaran takaful mikro yang dapat memberi kefahaman lebih jelas tentang kepentingan dan kesedaran menyertai takaful mikro kepada warga emas kumpulan ini.

\section{CADANGAN KAJIAN MASA HADAPAN}

Penyelidik mencadangkan kajian pada masa akan datang membincangkan pelaksanaan takaful mikro menggunakan dana daripada zakat, wakaf dan CSR bagi membolehkan takaful mikro dapat ditawarkan kepada golongan yang tidak mendapat perlindungan oleh takaful dan takaful sosial seperti warga emas.

\section{RUJUKAN}

Agensi Kaunseling dan Pengurusan Kredit, Celik Wang Pengurusan Wang secara Bijak (Kuala Lumpur: Agensi Kaunseling dan Pengurusan Kredit, 2014).

Agro Bank, 'Agro Mabrur-i,' laman sesawang Agro Bank, https://www. agrobank.com.my/product/agro-mabrur-i/., dicapai pada 6 April 2019.

AIA Public Takaful, 'AIA i-Starter,' laman sesawang AIA Public Takaful, https://www.aia.com.my/ms/our-products/life-protection/aia-i-starterplan/faq.html., dicapai pada 05 April 2019.

B. Zaheenah Chummun \& Christo A Bisschoff, 'A Perspective of Microinsurance (MI): The Case of South Africa,' Mediterranean Journal of Social Science, vol. 5/23 (2014): 63-71.

Brijesh C. Purohit, 'Policymaking for Diversity Among the Aged in India,' Journal of Aging \& Social Policy, vol. 15/4 (2003): 49-79.

Christian Biener \& Martin Eling, 'Insurability in Microinsurance Markets: An Analysis of Problem and Potential Solutions,' The Geneva on Risk and Insurance, vol. 37 (2012): 77-107.

Christian Biener, Martin Eling \& Joan T.Schmit, 'Regulation in Microinsurance Markets: Principles, Practice and Directions for Future Development,' World Development, vol. 58 (2014): 21-40. 
Craig Churchill, 'Insuring the Low-Income Market: Challenges and Solutions for Commercial Insurers,' The Genera Papers on Risk and Insurance, no. 32 (2007): 401-412.

Craig Churchill, 'Trying To Understand The Demand for Microinsurance,' Journal of International Development, vol. 14 (2002): 381-387.

Daniel J. Clarke \& Dermot Grenham, 'Microinsurance and Natural Disasters: Challenges and Options,' Environmental Science and Policy, vol. 27 (2013): S89-S98.

David M. Dror et al., 'Implementing A Participatory Model of Micro Health Insurance among Rural Poor with Evidence from Nepal,' The Geneva Paper, vol. 39 (2014): 280-303.

Farhana Hanim Mohd Mydin, 'Warga emas di Malaysia meningkat 2.8 juta orang,' KOSMO, http://ww1.kosmo.com.my/kosmo/content.asp?y=201 $6 \& \mathrm{dt}=0324 \& \mathrm{pub}=\mathrm{Kosmo} \& \mathrm{sec}=\mathrm{Negara} \& \mathrm{pg}=\mathrm{ne} \_02 . \mathrm{htm}$, dicapai pada 7 Mei 2018.

Fatin Nabilah Abdul Wahid \& Kamaruzaman Noordin, 'Skim Takaful Sumbangan Rendah serta Prospek Pelaksanaan Takaful Mikro di Malaysia,' (Paper presented, International Conference on Postgraduate Research (ICPR), Kuala Lumpur, 2014).

Haslifah Mohamad Hasim, 'Developing a Conceptual Framework of Microtakaful as A Strategy towards Poverty Alleviation,' Journal of Economics and Sustainable Development, vol. 5/28 (2014): 1-9.

Institut Penyelidikan Penuaan Malaysia, Universiti Putra Malaysia, Laporan Akhir Kajian Keberkesanan Bantuan Kewangan Jabatan Kebajikan Masyarakat, Kementerian Pembangunan Wanita, Keluarga dan Masyarakat (Putrajaya: Jabatan Kebajikan Masyarakat, 2017).

Jabatan Kebajikan Masyarat (JKM), 'Rumah Seri Kenangan (RSK), laman sesawang Jabatan Kebajikan Masyarakat (JKM), dicapai pada 13 Februari 2019.

Jacqueline Díaz Nieto et al., 'Weather Indices for Designing Micro-Insurance Products for Small-Holder Farmers in the Tropics,' Weather Indices for Micro-Insurance Product, vol. 7/6 (2012): 1-11.

James Midgley, 'Social Protection and the Elderly in the Developing World: Mutual Aid, Micro-Insurance and the State,' Journal of Comparative Social Welfare, vol. 28/2 (2012): 153-163.

Jamil Ramly et al., Buku Panduan Asas Takaful (Kuala Lumpur: IBFIM, 2010).

Joseph Oscar Aktey \& Charles K.D. Adjasi, 'Dose Microcredit Increase Household Welfare in the Absence of Microinsurance?' World Development, vol. 77 (2016): 380-394. 
Kementerian Kesihatan Malaysia (KKM), 'Warga Emas Terabai,' laman sesawang Portal Myhealth, http:/www.myhealth.gov.my/warga-emasterabai/, dicapai pada 9 April 2019.

Kementerian Pembangunan Wanita, Keluarga dan Masyarakat, 'Definisi Warga Emas,' laman sesawang Jabatan Kebajikan Masyarakat, http:// www.jkm.gov.my/jkm/index.php?r=portal/left\& id=VEpUUXV3THF URkZETmxWNjZpQ1BXdz09., dicapai pada 5 April 2019.

Kementerian Pembangunan Wanita, Keluarga dan Masyarakat, Dasar dan Pelan Tindakan Warga Emas Negara (Putrajaya: Jabatan Kebajikan Masyarakat, t.t.).

Lauren Peterson et al., 'Extending Health Insurance Coverage to the Informal Sector: Lessons from a Private Micro Health Insurance Scheme in Logos, Nigeria,' International Journal of Health Plan and Management (2018): 1-15.

Malaysia Takaful Association, 'Perlindungan Tenang' laman sesawang Malaysia Takaful Association, http://www.malaysiantakaful.com.my/ Consumer-Zone/Perlindungan-Tenang.aspx., dicapai pada 5 April 2019.

Markus Loewe, 'New Avenues to be Opened for Social Protection in the Arab World: The Case of Egypt,' International Journal of Social Welfare, no. 13 (2004): 3-14.

Michal Matual et al., 'Microinsurance Demand: Determinants and Strategies,' Enterprise Development and Microfinance, vol. 24/4 (2013): 311-327.

Mohammad Saleh Torkestani \& Pari Ahadi, 'Readiness Assessment of Islamic Micro-Finance Institution to Implement Micro-Insurance Concept (Case of Iran),' International Journal of Islamic and Middle Eastern Finance and Management, vol. 1/3 (2008): 249-261.

Mohammed Ahmad Uddin, 'Microinsurance in India: Insurance Literacy and Demand,' Business and Economic Horizons, vol. 3/2 (2017): 182-191.

Mohd Rizal Muwazir, Kamaruzaman Noordin \& Azian Madun, 'A Preliminary Study of Social Responsibility of Islamic Insurance Companies in Malaysia,' (Paper presented, International Conference on Art, Economics and Management (ICAEM'14), Dubai, 22-23 Mac 2014).

Mohd Uzir Mahidin, 'Jadual Hayat Ringkas, Malaysia, 2015-2017,' laman sesawang Jabatan Perangkaan Malaysia, https://www. dosm.gov.my/v1/index.php?r=column/pdfPrev\&id=bkJYT 3pXcDZGbjdiK3pWU0ZmNktoQT09., dicapai pada 6 Mei 2018. 
Nikunjkumar Gor, 'Microtakaful-Islamic Insurance For Deprived: Innovation, Sustainability and Inclusive Growth,' International Journal of Business, Economics and Law, vol. 3/2 (2013): 18-24.

Noor Ashikin Mohd Rom \& Zuriah Abdul Rahman, 'Financial Protection for the Poor in Malaysia: Role of Zakah and Micro-takaful,' Journal of King Abdulaziz University, Islamic Economic, vol. 25/1 (2012): 119-140.

Oscar Joseph Akotey, Kofi A. Osei \& Albert Gemegah, 'The Demand for Micro Insurance in Ghana,' The Journal of Risk Finance, vol. 12/3 (2011): 182-194.

Portal Rasmi Jabatan Kebajikan Masyarakat, 'Pengenalan,' laman sesawang Jabatan Kebajikan Masyarakat, http://www.jkm.gov. my/jkm/index.php?r=portal/left\&id=VEpUUXV3THFURkZET mxWNjZpQ1BXdz09, dicapai pada 5 April 2019.

Pradeep Panda, Arpita Chakrorty \& David M.Dror, 'Building Awareness to Health Insurance Among the Target Population of Community-based Health Insurance Scheme in Rural India,' Tropical Medicine and International Health, vol. 20/8 (2015): 1093-1103.

Prudential BSN Takaful, 'Lindungi,' laman sesawang Prundential BSN Takaful, https://app.prubsn .com.my/online/project/pruBSN/docs/LI_ Brochure_BM.pdf., dicapai pada 5 April 2019.

Rafiza Zuliani \& Asmak Ab Rahman, 'Micro-Takaful in Aceh: Does Society Need It?' dalam New Developments in Islamic Economics, ed. Asmak Ab Rahman (United Kingdom: Emerald Publishing, 2019).

Ralf Radermacher \& Johannes Brinkmann, 'Insurans for the Poor? First Thought about Microinsurance Business Ethic,' Journal of Business Ethic, vol. 103 (2011): 63-76.

Rebekah Yore \& Joanna Faure Walker, 'Microinsurance for Disaster Recovery: Business Venture or Humanitarian Intervention?: An Analysis of Potential Success and Failure Factors of Microinsurance Case Studies,' International Journal Disaster Risk Reduction, vol. 33 (2019): 16-32.

Said Adekunle Mikail, Muhammad Ali Jinnah Ahmad \& Salami Saheed Adekunle, 'Utilisation of Zakāh and Waqf Fund in Micro-takāful Models in Malaysia: An Exploratory Study,' ISRA International Journal of Islamic Finance, vol. 9/1 (2017): 100-105.

Seiro Ito \& Hisaki Kono, 'Why is The Take-up of Microinsurance so Low? Envidence from A Health Insurance Scheme in India,' The Developing Economies, vol. 48/1 (2010): 74-101. 
Sheela Chandran, 'Rancangan Simpanan Persaraan Menerusi Khidmat Nasihat KWSP,' laman sesawang Mstar, http://www.mstar.com.my/lain-lain/ suara/2016/12/30/kwsp-ras-perancangan-kewangan/., dicapai pada 8 Jan 2018.

Sheila Nu Nu Htay, Nur Shazwani Sadzali \& Hanudin Amin, 'An Analysis of the Viability of Micro Health Takaful in Malaysia,' Journal of Islamic Accounting and Business Research, vol. 4/1 (2015): 37-71.

Shuaibu Mukhtar, 'Insuring the Uninsurable for Poverty Alleviation in Nigeria: What Micro-Insurance can do?,' Mediterranean Journal of Social Science, vol. 4/2 (2013): 375-380.

Sirojudin \& James Midgley, 'Microinsurance and Social Protection: The Social Welfare Insurance Program for Informal Sector Workers in Indonesia', Journal of Policy Practice, vol. 11/1-2 (2012): 121-136.

Sonia Akter et al., 'Exploring The Feasibility of Private Micro Flood Insurance Provision in Bangladesh,' Disasters, vol. 35/2 (2011): 287-307.

Tajudeen Olalekan Yusuf, 'The Role of Islamic Micro Insurance in Economic Growth and Development: The Nigerian Experience: A Case Study of Al-Barakah Microfinance Bang, Lagos,' International Journal of Business and Commerce, vol. 1/10 (2012): 106-122.

Vishal Pinto, 'Role of NGOs in Promoting Micro Health Insurance: A Study with Reference to 'Sampoorna Saraksha' Health Insurance Scheme by SKDRDP, Mangalore (India),' South Asia Journal of Business and Management Cases, vol. 4/2 (2015): 251-261.

W. Kron, 'Flood Insurance: From Clients to Global Financial Markets,' Journal of Flood Risk Management, vol. 2 (2009): 68-75.

Wendy J. Werner, 'Micro-insurance in Bangladesh: Risk Protection for the Poor?' Journal of Health, Population and Nutrition, vol. 27/4 (2009): 563-573.

Yaya Koloma, 'Crop Microinsurance for Maize Farmers in Burkina Faso: Access and Agriculture Performance in Dandé Village,' Strategi Change: Briefing in Entrepreneurial Finance, vol. 24/1 (2015): 115-127.

Yi (Kitty) Yao, 'Development and Sustainability of Emerging Health Insurance Markets: Evidence from Microinsurance in Pakistan,' The Geneva Pepers, vol. 38 (2013): 160-180. 


\section{Temu bual}

Responden 1 (Ketua Penolong Pengarah Kanan, Bahagian Warga Emas (Cawangan Perkhidmatan Institusi), Jabatan Kebajikan Masyarakat), dalam temu bual beliau bersama penulis pada 22 November 2018.

Responden 2 (Penolong Pengarah, Bahagian Kebajikan Produktif, Jabatan Kebajikan Masyarakat), dalam temu bual beliau bersama penulis pada 22 November 2018.

Responden 3 (Ketua Penolong Pengarah, Bahagian Komuniti (Cawangan Pertubuhan Sukarela Kebajikan), Jabatan Kebajikan Masyarakat), dalam temu bual beliau bersama penulis pada 13 Februari 2019.

Responden 4 (Penganalisis, Jabatan Perbankan Islam dan Takaful, Bank Negara Malaysia), dalam temu bual beliau bersama penulis pada 15 Februari 2019.

Responden 5 (Penolong Pengurus, Jabatan Pemasaran Produk, AIA Public Takaful), dalam temu bual beliau bersama penulis pada 6 Mei 2019.

Responden 6 (Ketua, Jabatan Takaful Mikro dan CSR, Prudential BSN Takaful), dalam temu bual beliau bersama penulis pada 15 Mei 2019.

Responden 7 (Pengurus, Jabatan Takaful Mikro dan CSR (Produk), Prudential BSN Takaful), dalam temu bual beliau bersama penulis pada $15 \mathrm{Mei}$ 2019.

Responden 8 (Pengurus, Jabatan Takaful Mikro dan CSR (CSR), Prudential BSN Takaful), dalam temu bual beliau bersama penulis pada 15 Mei 2019.

Responden 9 (Timbalan Presiden, Jabatan Bancatakaful, Takaful Ikhlas), dalam temu bual beliau bersama penulis pada 12 Jun 2019. 